\title{
Imaging Pores in Sedimentary Rocks: Foundation of Porosity Prediction
}

\section{${ }^{\mathrm{a}}$ Bureau of Economic Geology}

University of Texas at Austin

Austin, Texas 78713

${ }^{b}$ Mewborne School of Petroleum and Geological Engineering University of Oklahoma Norman, Oklahoma 73019

*Corresponding author.

Email address: Kitty.milliken@beg.utexas.edu

(C) 2016. This manuscript version is made available under the Elsevier user license http://www.elsevier.com/open-access/userlicense/1.0/ 


\subsection{INTRODUCTION and BACKGROUND}

The term "pore" applied in this review (section 1.1) is underlain by the notion that pores are fundamental rock components that, given a suitable imaging method, one might actually see. Modern concepts of pore interpretation and methodologies of pore imaging grew first from studies of coarser sedimentary rocks, sandstones and limestones, and we begin our paper with an examination of this body of work. We review the technological means, both sample preparation and imaging methodologies, that underpin current models for porosity evolution in sedimentary rocks and that serve efforts to extend this understanding to pore systems in the fine-grained sedimentary rocks known as mudstones or shales. In the second half of the paper we consider specifically the current work on pore imaging in muds and mudstones. In some cases, these smallest sedimentary pore systems may be simple analogues of coarser systems, but in other cases, processes in small pores may depart from significantly from those in coarser systems because of the special chemistry and physics that apply at the nanoscale.

\subsection{What is a pore?}

Pore volume can be considered, most simply, the portion of the total rock volume that is not solid. This viewpoint naturally enables other essential notions: 1 . Pores are defined by pore walls. To fully understand the nature of a pore it is essential to discern the character of pore walls; 2. Any particular method of observation (and, indeed, any particular means of bulk measurement) detects only a portion of the total pore population as there are always pores that are blocked from view or too small or too large to be appreciated from a particular image or with a particular method, and, 3. In the Earth's crust pores are never empty---they are not "voids", but host components such as water with dissolved solids, petroleum liquids, gases, a mixture of these or, in the deeper subsurface, a supercritical fluid (Fyfe and Thompson, 1978; Strumm and 
Morgan, 1996; Tissot and Welte, 1984). Some pores host living organisms (e.g., de la Torre et al., 2003; Kennedy, 1993). Over geologic history pore contents have mobility greater than that of crystalline or other solid rock components (Goff and Williams, 1987; Morad et al., 2000; Parnell, 1994).

The relative mobility of pore contents is responsible for a fourth and quite interesting aspect of pores in sedimentary rocks: the fact that pores change in size, shape, and abundance over time as the rock's solid and mobile volumes respond to shifting chemical and physical conditions in the subsurface. For example, movement of pore contents under sediment loading allows compaction whereas restriction on fluid movement (overpressuring) may retard it. Transport of dissolved components within the mobile rock volume permits dissolution and precipitation of mineral volumes that also yield corresponding changes in the pore volume, both increases and decreases, as pore walls are modified. This paper reviews the various technologies for observing pores in sedimentary rocks and describes some of the outcomes from visual inspection of pores and interpretation of pore histories that have led to models for prediction of subsurface porosity.

\subsection{Why look at pores?}

Bulk analysis of porosity and pore size distributions in sediments and sedimentary rocks is accomplished by several methods, each with advantages and disadvantages (Doveton, 2014; American Petroleum Institute, 1998; Luffel et al., 1996; Pearson, 1999; Schön, 2015; Tiab and Donaldson, 2015; Van Geet et al., 2000). A key disadvantage to all methods of bulk analysis relates to the limited manner in which such methods contribute to pore classification. Pores can be classified by absolute size (e.g., Luxmoore, 1981; Nelson, 2009; Zdravkov et al., 2007) although a notable challenge concerning the use of size categorization for pores is that an 
arbitrary name (e.g., "mesopore") applied to a given size range may vary across fields of study or even among different authors in the same field. Pores may also be categorized by relative size (Etris et al., 1988; Lucia, 1995) and by shape (Desbois et al., 2009; Ehrlich et al., 1991). In rocks such categories as size and shape pertain only to the final state of a bulk material that may have undergone substantial change over a history of mechanical and chemical modification (Fabricius, 2007; Katsube and Williamson, 1994). The final size (relative or absolute) and shape of a pore, by themselves, provide only weak clues to the nature and causes of changes responsible for porosity evolution because a given size or shape may arise by multiple pathways of modification .

Although bulk measurements of porosity and knowledge of pore size and shape have tremendous utility for modeling storage and flow behavior, pore categorization that is not referenced to the initial geometry of the rock fabric (solids and pores) is inherently handicapped for assessment of porosity evolution as it lacks information that can be related to timing, mass transport, and volume changes related to mass transport. Prediction of porosity evolution depends heavily on understanding of the local material imports and exports that have affected pore walls of known origins. Pore categorization referenced to the primary detrital framework, a state against which subsequent change can be measured, has a powerful advantage for use in porosity prediction and can only be accomplished by inspection.

Compactional strain (volume loss through mechanical pore collapse) is an important rock modification that can be referenced to the primary depositional framework (Ehrenberg, 1995). Similarly, assessment of mass-balance, the measure of volume losses and gains affecting the mineral fraction, requires an understanding of the primary detrital assemblage as a starting point against which change can be measured (Milliken et al., 1989; Milliken et al., 1994). Whether a 
post-depositional precipitate occupies a primary pore versus a secondary pore (no matter the size) has immense ramifications in terms of the balance of local elemental imports and exports required. Both pore volume and mineral volumes change during rock history and not always in a simple inverse relationship. A mineral (or solid volume) gain does not necessarily result in a pore loss if it is preceded or accompanied by a loss in the mineral volume (secondary pore formation). A mineral (or solid volume) loss does not equate to porosity gain if it is accompanied or followed by compactional collapse or mineral precipitation. Assessing these complex historical exchanges between pore and solid volumes depends upon assessment of paragenesis by imaging.

\subsection{Pore categorization based on paragenesis}

Primary pores are present at the time of deposition and these can be intergranular (between the detrital particles) or intragranular (contained within a particle). Primary intergranular pores are the dominant primary pore type within most sandstones and mudrocks (Figure 1), even after a protracted history of diagenesis (Milliken et al., 2007; Paxton et al., 2002; Scholle and Ulmer-Scholle, 2003). Some carbonate sediments and also some mudrocks contain significant primary intragranular pores (Figure 2) if complex fragments of bioclastic debris or vesicle-rich pumice are abundant in the grain assemblage (Milliken and Choh, 2011; Milliken et al., 2007; Scholle and Ulmer-Scholle, 2003) (Figure 1). The primary intragranular pores within biogenic particles represent spaces formerly filled by the living tissue of the organism and also structural elements that allowed movement of fluids through the shell wall.

Primary pores, both inter- and intra-granular, are subject to modification by mechanical and chemical processes in diagenesis. Grain rearrangement and brittle and ductile grain deformation are microscale mechanical processes that operate to reduce primary pores in compaction (Chester et al., 2004; Kopf and Behrmann, 1997; Pittman and Larese, 1991); in 
carbonate sediments chemical processes may also play a role (Croize et al., 2010). Cements are minerals precipitated from aqueous solution (authigenic minerals) into primary pore space (Milliken, 2003; Milliken and Day-Stirrat, 2013). Organic matter of diagenetic origin (residual hydrocarbon) can fill pores in a manner analogous to cement (e.g., Huc et al., 2000; Moller and Friis, 1999).

Secondary pores form after deposition, mostly through dissolution of the primary detrital grains or, less commonly, through dissolution of diagenetic elements such as cements and grain replacements (e.g., McBride, 1977; Pettijohn, 1941; Schmidt and McDonald, 1979a) (Figure 3). Fracture pores are a type of secondary pore, and thus, both mechanical and chemical processes influence the formation of secondary pores. Terminology for secondary pores is complex and relates to spatial occurrence of the pore relative to the detrital framework (e.g., intragranular secondary pores, moldic pores, oversize pores) or the larger-scale fabric of the rock (e.g., fracture pores of intragranular, transgranular, or circumgranular types). Fracture pores arise from breakage and separation of the solid rock volume. Simple intragranular fracture pores clearly arise from a redistribution of the primary porosity (Makowitz and Milliken, 2003), but the derivation of the space within most through-going transgranular fractures is generally unclear. The relative timing of pore modifications relative to deformation (Laubach et al., 2010; Laubach and Milliken, 1996) also factors into the terminology for cements and grain replacements (e.g., synkinematic cements). An alternative mechanism of secondary pore development, and one of considerable current interest in research, relates to processes that occur during thermal maturation, for example by gas bubble formation or by volume loss from organic matter (kerogen or residual hydrocarbons) during thermal cracking (Loucks et al., 2009). 
Grain replacement denotes authigenic minerals precipitated within a space formerly occupied by a dissolved grain, regardless of the relative timing between dissolution and precipitation (Milliken, 2003). Ascertaining the timing between grain dissolution and mineral precipitation within the resulting secondary pore is one of the greatest challenges in paragenetic assessment. Grain replacements seldom share the precise mineralogy of the dissolved grains and the elemental imbalances thus imposed have to be satisfied by elemental imports and exports that require aqueous transport (e.g., Fedo et al., 1997; Milliken, 2004; Milliken et al., 1994; Nedkvitne et al., 1993; Wolela and Gierlowski-Kordesch, 2007). Replacement may occur nearly synchronous with dissolution across interfaces that represent only the smallest of fluid films (Merino et al., 1993), or, alternatively, may occur long after grain dissolution and within macroscopic pores that existed for a prolonged period before being filled. The petrographic means to discriminate the above scenarios are unclear in many cases, but the fact that most grain replacements are accompanied by intergranular cements of the same composition (Milliken, 1989) argues that secondary pores provided sites for cement nucleation essentially equivalent to sites in intergranular pores (Milliken, 2003). Complete filling of secondary pores is unlikely in such a situation and this type of replacement is associated with much preserved secondary porosity. Situations in which grain replacements display a preferential localization on dissolved grains (e.g., Milliken 2003) argue for a tighter association between dissolution and precipitation (Maliva and Siever, 1988) with little or no associated secondary pore development (Figure 4). Processes of pore modification through cementation, dissolution, and grain replacement can be so profound as to impart a complete inversion of the pore distribution, what was once solid material becoming pore while what was once pore becomes solid (Figure 5). 
Grain replacements in particular cause loss of information on pore paragenesis as diagenetic modification becomes extreme. As mentioned above, because grain replacements are precipitates from an aqueous solution that fills the pores, they are typically accompanied by cements of similar composition and timing (Milliken, 1989). If the growth of authigenic minerals as simultaneous grain replacements and cements becomes pervasive and large, the grain/intergrain fabric that defines sedimentary materials can be erased (Figure 6). In such a case it becomes necessary to characterize pores as "intercrystalline", "intracrystalline", or, perhaps, "fracture-fill" without reference to the context of the original grain framework. Such pores dominate within rocks that have lost their sedimentary fabrics during metamorphism but also within rocks such as crystalline dolomites that are still generally considered sedimentary (e.g., Machel and Anderson, 1989; Murray, 1960). Assessment of the timing and mechanisms of processes responsible for such pores is extremely challenging because mass exchanges cannot be related to a known primary detrital framework.

\subsection{Historical Context: Pore Imaging in Sandstones for Conventional Reservoir}

\section{Characterization}

Use of impregnation media for the stabilization of friable specimens prior to thin section preparation is a technique dating to the late $19^{\text {th }}$ century (Wilkinson, 1900). Addition of color to the impregnation material was done in the 1940s (Lockwood, 1950) and perhaps earlier, although this technique did not become widely practiced and commercially available until the late 1960s. The idea behind colored impregnation media (typically some type of plastic resin) is to inject rock pores with the colored medium prior to thin sectioning, such that natural pores appear in a distinctive color whereas pores created by mechanical damage during cutting, 
grinding, and polishing the section are filled only with the clear adhesive used to attach the rock slice to the supporting glass slide (Figure 7).

In the late 1960s to mid-1970s widespread application of this simple technology for coloring pores prior to visual observation, brought about a radical transformation in the understanding of pore evolution as the widespread occurrence of secondary pores within former grain volume was recognized (Hayes, 1979; Lindquist, 1977; McBride, 1977; Pittman, 1979; Schmidt and McDonald, 1979b; Stanton, 1977), confirming and expanding upon the earlier observations of Pettijohn (1941). Prior to application of colored impregnation media, direct observations pores and the evolution of pores were rarely mentioned and work on porosity evolution focused mostly on experimental approaches (Allen and Chilingarian, 1975; Maxwell, 1960) and modeling of porosity assessed through bulk, and often, indirect, measurements such as bulk density, velocity, or log-derived porosity (Athy, 1930; Weller, 1959). An exception is the work by Taylor (1950) that approached the problem by examining grain contacts, thereby cleverly avoiding the necessity of measuring the porosity. By the 1970s, however, the availability of colored impregnation media had fostered development of a complex terminology for pore description (as described above) and novel approaches to quantitative partitioning of total porosity across specific pore types through the use of imaging data. A key discovery was that total porosity as determined by bulk measurement is an unsuitable proxy for intergranular space. To quantify the role of compaction in subsurface porosity decline it is necessary to use observational methods that account for the primary intragranular pores within grains, the filling of intergranular pores by mineral precipitates (cements), and the generation of secondary pores. Following soon upon this development research laboratories at major oil companies, hoping to develop empirical methodologies for reservoir quality prediction (e.g., papers in Wilson, 1994) 
amassed large petrographic databases for sandstones. An important development arising from this data collection effort was the concept of intergranular volume (IGV, Paxton et al., 2002; Szabo and Paxton, 1991).

(1) $\mathrm{IGV}=$ intergranular pore space + intergranular cement $+($ detrital matrix $)$ all parameters expressed as a percent of total rock volume In older literature IGV is also known as the "minus-cement porosity" or the "pre-cement porosity". Of key importance is the omission of both primary intragranular and secondary intragranular pores from IGV.

Application of equations denoting compactional change referenced to the initial sediment bulk volume (compactional porosity loss, COPL; Ehrenberg, 1989):

(2) $\mathrm{COPL}=\mathrm{P}_{\mathrm{i}}-\left(\left(\left(100-\mathrm{P}_{\mathrm{i}}\right) * \mathrm{IGV}\right) /(100-\mathrm{IGV})\right.$

where $\mathrm{P}_{\mathrm{i}}$ is the initial intergranular porosity and all parameters are expressed as a percent of total rock volume

led to the recognition of compaction as the dominant cause of subsurface porosity decline in sandstones (Lundegard, 1992). Because visualization of mineral components in rocks is readily accomplished, cementation has long been recognized as a factor in porosity decline in sandstones (Fothergill, 1955; Gilbert, 1949; Goldstein, 1948; Johnson, 1920; Lerbekmo, 1961). Because compaction and cementation operate in concert however, a quantitative understanding of cementation did not advance until the role of compaction was clarified and isolated as described above. Cementational porosity loss (CEPL) can also be referenced to the initial sediment volume (Ehrenberg, 1989; Lundegard, 1992):

(3) $\mathrm{CEPL}=\left(\mathrm{P}_{\mathrm{i}}-\mathrm{COPL}\right) *(\mathrm{C} / \mathrm{IGV})$ 
Where $\mathrm{C}$ is the volume of intergranular cement and all parameters are expressed as a percent of total rock volume.

COPL and CEPL observed in large petrographic data sets for sandstones (Lundegard, 1992) established that compaction is the dominant cause of porosity decline in the subsurface. The wide variation in these parameters led next to the recognition that the composition of the primary detrital grain assemblage exerts a strong control on the progress of compaction, a concept that was verified by observation (Smosna, 1989) and experiment (Pittman and Larese, 1991). Sandstones that contain an abundance of ductile grains (typically fine-grained lithic fragments of sedimentary, volcanic, or metamorphic origin) may lose almost all intergranular pore space to compaction whereas sandstones composed dominantly of rigid grains (quartz and feldspar) follow a different pathway of compactional strain (Pittman and Larese, 1991). In either case, compaction can be modeled as an exponential curve with the rate of decline with effective stress adjusted to reflect the behavior of the ductile and rigid grains in the overall grain assemblage (Lander and Walderhaug, 1999).

Recognition that rigid-grain sand packs achieve compactional stabilization at an IGV of around $26 \%$ at a depth of 1.5 to $2.0 \mathrm{~km}$ further established that intergranular porosity values below $26 \%$ in such a grain pack must arise by cementation (Paxton et al., 2002).

Attempts to model the progress of pore loss through cementation, in particular quartz cementation, have benefited from another imaging technology, cathodoluminescence, which can be performed on both light-microscope and electron-microscope systems. The early work of (Sippel, 1968) showed that many apparently sutured contacts between adjacent quartz grains were in fact compromise growth boundaries between cement crystals nucleated on opposing pore walls. With the advent of SEM-based CL systems in the early 1990s Sippel's observations were 
widely confirmed and the previously popular pressure solution model (de Boer, 1977; Lehner, 1995) was largely abandoned as an explanation of porosity decline in sedimentary basins. At about the same time systematic study of deep sedimentary basins having simple burial histories (e.g., Land et al., 1987) and exacting fluid inclusion work on zoned quartz cements (Walderhaug, 1994, 1996) elucidated the strong thermal controls on the growth of quartz cement, leading to integrated models for compaction and cementation of great practical efficacy (Ajdukiewicz and Lander, 2010). Today pore-scale reservoir quality is modeled using empirically calibrated kinetic approaches that yield a fairly tight envelope of prediction (Taylor et al., 2004; Taylor et al., 2010; Taylor et al., 2015; Tobin et al., 2010).

A key point is that an understanding of paragenesis, founded upon imaging, was at the root of this predictive understanding of subsurface sandstone porosity. Technologies such as colored impregnation media and cathodoluminescence imaging revealed the processes that control porosity evolution (compaction and cementation) and a fostered a quantitative assessment of the progressive outcomes of those processes operating in the subsurface. In turn, models founded upon a correct understanding of process achieved great accuracy and precision in prediction (Taylor et al., 2004; Taylor et al., 2010; Taylor et al., 2015; Tobin et al., 2010).. The following sections of this paper examine current technologies for imaging of pores in sedimentary rocks, with particular emphasis on mudrocks and the quest to derive a predictive understanding of porosity evolution in the Earth's most abundant sedimentary materials. Imaging of the extremely small components in mudrocks at a scale appropriate to evaluating the processes affecting those components has only recently become widely available to the geoscience community that is interested in predicting mudrock properties and further advances in observational science are needed before process-based prediction models can be devised. 


\subsection{Imaging methods for sedimentary rocks}

The currently available toolkit for imaging sedimentary rocks is extensive (Table 1). The light microscopy that was available from the middle of the $19^{\text {th }}$ century (Folk, 1965; Summerson, 1976) has been joined by a wide array of imaging techniques based upon interactions between specimens and energized probes. Short-wavelength light, laser light, electrons, X-rays, neutrons, ions of various charge and weight, and acoustic and mechanical energy are some of the options beyond visible light that are available for investigating rock components and fabrics. The direct interaction of energetic probes with the material forms the basis of some methodologies and signals secondarily generated by the interaction also can be detected, leading to the great variety of imaging tools listed in Table 1. Some methods, such as back-scattered electron imaging, are broadly applicable to the full range of materials that are commonly found in sedimentary rocks where as other tools, are most useful with respect to some narrower range of material such as organic matter (e.g., CARS) or a subset of mineral components (e.g. CL).

All imaging methods have a characteristic upper and lower limit to their operating magnification and it is important to note that the theoretical maximum resolutions may not be readily achieved in routine imaging efforts. Finally, methods that are optimized to provide information on pores, pore sizes, and pore-size distributions, especially at very small scales, are not in many cases the best methods for understanding the composition and historical context of the pore walls and vice versa. For example, the electron beam energies required to generate signals for X-ray elemental mapping (EDS and WDS) create beam widths and interaction volumes within the specimen that are not compatible with imaging resolutions sufficient to see pores in mudrocks. Obtaining imaging information on size, shape, and composition on mineral, organic matter, and pore components necessarily requires application of multiple methologies 
across a variety of scales. Techniques highlighted in red Table 1 are ones that offer both high spatial resolutions and compositional information that potentially can advance our understanding of pore paragenesis at the nanoscale.

Careful sample preparation is crucial for obtaining meaningful results from any imaging method. It is important to understand the limitations of any preparation method as well as potential preparation-related artifacts which can lead to misinterpretation of the imaging or analysis results. In addition, it is important to consider how a specific sample preparation fits into the imaging workflow when multiple imaging technologies are employed so as not to interfere with subsequent measurements. For many micro- and nano-porous rock samples, simple mechanical polishing such as used for optical thin sections of coarser grained materials is too coarse of a method to see the smallest pores because artifacts from mechanical damage in polishing (holes from pitting and plucking) are similar in scale to natural pores. To overcome this, ion milling (Heaney et al., 2001) is utilized to create the highly polished surface with minimal artifacts that is necessary for SEM, TEM, STEM, EDS, EELS, and CL (Loucks et al., 2009; Sondergeld et al., 2010b). There are two types of ion milling: Broad Ion Beam (BIB) which typically utilizes argon ions and Focused Ion Beam (FIB) imaging which typically utilizes gallium ions. BIB is preferred for most 2D SEM imaging and analysis of sedimentary rocks because of the relatively large area, upwards of an inch diameter, that can be milled in a few hours, provided sufficient mechanical polishing of the sample has been done beforehand (Curtis et al., 2014; Goergen et al., 2014). FIB (Figure 8) is primarily reserved for 3D FIB-SEM and TEM sample preparation because of the relatively small area that can be milled in a given time. The FIB is well suited for these imaging methods in that it can be mounted on the same sample chamber as the SEM for imaging purposes and the focus and position of the ion beam can be 
controlled for precision milling. The two artifacts that are a common concern for any ion milled sample are curtaining artifacts (Figure 8C) and sputter-redeposition (Figure 8D) (Phaneuf, 2005). One should also be aware of beam damage to sensitive structures,, as this is often is a problem in TEM in the form of the generation of an amorphous layer (Phaneuf, 2005). Milling artifacts can be mitigated with proper care in choosing sample position, milling times, and energies of the ion beam. .

\subsection{Current research: Imaging pores in fine-grained sedimentary rocks}

\subsection{Challenge: Imaging very small pores}

Fine-grained sedimentary rocks (known as mudstones, mudrocks, or shales) have the same range of primary and secondary pore types as observed in sandstones and limestones, as least insofar as can be determined from pores that can be imaged (Gale et al., 2014; Krinsley et al., 1998; Milliken, 1992; Milliken and Day-Stirrat, 2013; O'Brien and Slatt, 1990) (Figure 9).

Typically, the largest pores in fine-grained sediments are those associated with primary intragranular spaces within intact skeletal grains, but such pores tend to have localized distributions. Primary intergranular pores in lithified mudrocks tend to be filled with cement (see next section). Fracture pores (Figure 9C) may constitute some of the largest pores present in lithified mudrocks (Gale et al., 2014), however further research is needed into the quantitative contributions of fracture pores to the total pore system. Few fracture pores are encountered at the scale of imaging required to view the dominant intergranular and secondary pores in mudrocks (Gale et al., 2014).

The dominant intergranular pores in muds are intrinsically small. The high porosity that characterizes fine-grained sediments at deposition (up to 80 percent) is diminished by compaction within the first few meters of burial (e.g., Bartholdy et al., 2010; Velde, 1996), but 
porosities in the range of 30-40 percent remains even at depths of around $1 \mathrm{~km}$ (Day-Stirrat et al., 2012; Velde, 1996). In this early stage of burial, intergranular pores in muds are generally no larger than a micrometer at even at shallow burial depths of a few meters below the seafloor (Figure 9A). The largest intergranular pores in the early compaction of mud are typically affiliated with packing flaws and sheltered spaces immediately adjacent to silt particles (DayStirrat et al., 2010; Desbois et al., 2009; Milliken and Reed, 2010; Oertel, 1983; Schneider et al., 2011). The intergranular pores interstitial to clay-size particles are exceeding small, generally measured in nm or tens of nm (Desbois et al., 2009; Milliken and Reed, 2010).

At early stages of burial, in muds with porosity in the range of 40-60 percent, SEMdetermined porosity matches closes the porosity measured by adsorption or other bulk methods (Nole et al., in review). However, in mudrocks that have undergone considerable compaction and cementation much of the total porosity (as much as 70 to 90 percent) is not detected by SEM imaging (Keller et al., 2011a; Keller et al., 2011b; Milliken et al., 2013). Many mudrocks that have experienced a protracted history of diagenesis lose even the pores in the range of 10s to 100s of nm (Milliken et al., 2013). Pores in the range of $2 \mathrm{~nm}$ size or smaller overlap the size of spaces related to crystal site vacancies and other crystal defects, intercrystalline spaces within clay minerals and zeolites, and crystal boundary fluid films, all features that, historically, generally have not been considered as part of the porosity. If such small spaces host mobile phases such as water or gases, however, these small spaces are detected as pores from the perspective of many forms of bulk analysis (e.g., NMR) and also by imaging at the highest available, but not widely applied, TEM and HIM resolutions (Table 2). There remains great uncertainty as to the genetic classification of the smallest pores $(<100 \mathrm{~nm})$ : Are the smallest pores primary intergranular pores, intragranular pores inherited from the source rock, or 
secondary pores relating to post-depositional processes that have mobilized the grain volume into the pore fluid? Answering such questions depends upon methods of imaging that provide some information on the composition of the solids that constitute the pore walls (Figure 10).

\subsection{Challenge: Imaging very small cement crystals}

A key knowledge gap related to porosity prediction in fine-grained sediments is that the IGV concept has yet to be refined for these materials, the principle obstacle being a lack of information about the progress of cementation (Giles et al., 1998; Milliken and Day-Stirrat, 2013). The literature contains an abundance of porosity decline curves for fine-grained sediments over depth ranges from the surface to $5 \mathrm{~km}$ of burial (reviewed by Mondol et al., 2007), the greater number of which are based on proxy measurements (e.g., density or velocity). Such values for porosity decline cannot be applied as compaction curves until the role of cementation is assessed.

The greatest challenge to assessing cementation in muds, of course, is that, as described above, the pore spaces available for cement emplacement are generally quite small. Thus, pursuit of cement studies in fine-grained sediments requires high-resolution imaging methods. The rare larger pores found locally within skeletal fragments or fractures present a window for assessing the processes that potentially affect smaller pores (Figure 11; further examples provided in Milliken and Day-Stirrat, 2013, their Figure 5, p. 14), but do not fully confirm the nature of processes operative in the smallest pores.

Quantitative assessment of cements within mudrock pores requires imaging methods that not only resolve the pores and pore-fills at submicrometer scales and but also provide 
compositional information that allows discrimination of pore walls made of primary (grain) versus secondary (cement, grain replacement, or residual hydrocarbon) components.

X-ray mapping by EDS and cathodoluminescence are key methodologies for compositional imaging but have resolution limits that are not fully satisfactory for observing cements in mudrocks (Figure 10). Sample preparation methods that yield sample thinness smaller than interaction volumes for X-ray and CL generation may extend the utility of these methods for cement inspection. Imaging techniques such as TEM and HIM that provide ready access into magnifications that reveal the smallest pores have not been extensively integrated with compositional information, for example from EELS. Techniques such as charge contrast imaging (Watt et al., 2000), nano-SIMS (Elphick et al., 1991), and SXRF (Pushie et al., 2014) may also assist cement characterization at very small sizes.

\subsection{Challenge: Imaging across scales}

Another challenge for assessing porosity evolution in fine grained systems concerns the careful integration of imaging observations across scale because at the size of the smallest pores it becomes quite difficult to assess the nature of the surrounding materials (grains, cements, grain replacements, detrital organic matter, or diagenetic organic matter). In mudrocks, in almost every case, crystals are larger than associated pores, and this contrast becomes relatively greater for the smallest pores. Thus, it is intrinsically difficult to characterize both pores and crystals at a single imaging magnification. Keeping track of the identity of particular crystals and other solid materials (kerogen and residual hydrocarbons) while applying the imaging scales appropriate for characterization of associated pores is one of the central challenges of small pore characterization. Benefits of the highest resolution imaging will be easiest to gain if samples are placed through a sequence of inspection steps, beginning with light microscopy and then moving 
through more conventional SEM-based approaches before higher-resolution techniques such as HAADF, SANS, or SAXS are attempted. Performing imaging across such a range of scales will inevitably confront issues of conflicting sample preparation requirements. Detailed knowledge of sample heterogeneity across a range of scales, even if it cannot be gleaned entirely from a single field of view, will provide vital context for the paragenetic classification of pores that will serve the goals of pore prediction. Imaging techniques that provide both high-resolution and compositional information (e.g., EELS, HAADF, SANS, SAXS, SXRF) are of special interest. Efforts to extend the reach of compositional imaging methods such as BSE, EDS, and CL to finer scales are particularly worthy of research attention.

\subsection{Challenge: Possible contrasts of porosity evolution in finer versus coarser sediments}

\subsubsection{Compaction}

Both observation (Day-Stirrat et al., 2012; Milliken and Reed, 2010; Yang and Aplin, 2007) and experiment (Dewhurst and Aplin, 1999; Emmanuel and Day-Stirrat, 2012; Mondol et al., 2007; Schneider et al., 2011) show that pore loss in mudrock compaction is size-dependent, larger pores being more easily collapsed in response to effective stress. The smallest size range

of pores $(<100 \mathrm{~nm})$ seem especially resistant to mechanical collapse (Dewhurst and Aplin, 1999; Emmanuel and Day-Stirrat, 2012). Mudstones that have undergone a protracted history of diagenesis have very low porosities and modal pore sizes in the range of a few nm (Aplin et al., 2006; Katsube and Williamson, 1994; Milliken et al., 2012). The small modal pore sizes (generally less than $4 \mathrm{~nm}$ ) in organic matter-hosted pore systems (Milliken et al., 2013) suggests that these may be residual pore populations that remain because frictional forces acting on bubbles of very small size are too great to allow them to migrate under compactional loading (Brown, 2000). 

porosities below $10 \%$ observed in mudrocks with more extensive diagenesis (typical of oil and gas shales) there is a considerable gap in our understanding of the mechanisms that drive porosity decline. Compactional stabilization of rigid sand grain packs leads to the conclusion that cementation is the dominant mechanism of porosity decline in sandstones at depths greater than 1.5 to 2.0 kilometers (Paxton et al., 2002), but whether there is an analogous depth of compactional stabilization in muddy sediments is unknown.

As mentioned in the preceding review of sandstone porosity prediction, grain composition is a major control on the compactional path. Compositional variety of grain assemblages in fine-grained sediments is large, spanning the full range of what is observed in sandstones and limestones with the addition of the substantial detrital clay mineral content (Milliken, 2014). That fine-grained grain assemblages should display a similar variety of compactional response across compositional variation seems a plausible hypothesis but this idea has not been fully tested.

Experimental work on compactional response of siliciclastic muds having different silt/clay ratios (Day-Stirrat et al., 2012; Dewhurst and Aplin, 1999; Schneider et al., 2011) demonstrate the control of grain sorting on packing flaws that lead to higher porosity and permeability in siltier grain mixtures. However, the impact of differing mineralogical compositions of the silt- and clay-size particles, for example the response of carbonate-rich sediments versus siliciclastic ones, or inorganic versus biogenic sediments, has not been explored. It is also expected that grain assemblage composition will affect the path of cementation because grains of different composition differ widely in chemical reactivity and this 
in turn may further modify compaction. Fine-grained assemblages that are rich in biogenic carbonate and opal and also volcanogenic grains may be prone to early cementation that substantially inhibits compaction (Aplin and Macquaker, 2011; Macquaker et al., 2014; Milliken, 2014).

To date, efforts to apply quantitative IGV measurement and porosity decline assessment (equations 1-3) in rocks other than sandstones been limited (e.g., Budd, 2002; Melzer and Budd, 2008) and this relates in part to the challenges of imaging very small pores and pore fills as described above. Another challenge for compaction modeling is the presence of abundant primary intragranular pores in some mudrocks. If the primary intragranular volume in mudrocks is subject to the same compactional reduction as intergranular pores (an assumption that needs to be tested) a similar numerical approach to measuring compactional strain might be applied in limestones and mudrocks that contain abundant primary intragranular pores. In such an approach the total primary porosity (primary intergranular porosity plus primary intragranular porosity) could be substituted for IGV and a cement value that includes intragranular cement can be substituted for intergranular cement, assuming the primary versus secondary origin of the intragranular space can be determined.

\subsubsection{Cementation}

Theoretical reasons can be raised to support contradictory ideas about cementation in mudrocks. On one side it can be postulated that mudrocks may be more prone to cementation than coarser sediments because in some cases they contain highly reactive grain assemblages that provide abundant solutes that lead to precipitation (Milliken, 2014) and also because their very fine constituent particles provide ample surface area to favor nucleation. 
Finally, observations in sandstones show a counter-intuitive negative correlation between the grain size of detrital quartz (and total surface area) and quartz cement growth (Lander et al., 2008; Makowitz and Sibley, 2001). The slower growing crystal faces that ultimately dominate are expressed more quickly in smaller crystals, thus imposing slower overall rates on smaller nucleation substrates and lesser ultimate cement volumes (Lander et al., 2008). This crystallographically controlled growth that leads to cement thickness variations, evident in grain populations of sand-size (> $62.5 \mu \mathrm{m}-2.0 \mathrm{~mm}$ ), is expected to be even more strongly manifest on quartz particles of coarse clay- to silt-size $(1 \mu \mathrm{m}-62.5 \mu \mathrm{m})$. It is possible however that available pores in mudrocks are so small that growing crystals may contact the pore walls before crystal growth rates are slowed by development of euhedral faces (Lander and Laubach, 2015).

\subsection{Challenge: Placing organic matter components into paragenetic context}

Recent interest in unconventional resources has brought considerable attention to organic-rich mudrocks (Howarth et al., 2011; Jarvie et al., 2007; Montgomery et al., 2005; Passey et al., 2010; Sondergeld et al., 2010a). New techniques for sample preparation by Ar-ion cross-section polishing (described above; Loucks et al., 2009) allowed more confident interpretation of mudrock pores that were ambiguous in samples prepared as broken surfaces or by mechanical polishing (Figure $8 \mathrm{~A}$ and $\mathrm{B}$ ) and application of this technique reveals that the $\mathrm{OM}$ component hosts an important portion of the total porosity in some mudrocks (Loucks et al., 2009; Milliken et al., 2013; Passey et al., 2010). Examination of OM-hosted pores using SEM techniques has naturally led to the examination of the OM itself (e.g., Bernard et al., 2012b; Fishman et al., 2012) and work is on-going to reconcile these small-scale observations to the larger body of organic petrology that is based on reflected light microscopy (Stach and al., 1982) 


\subsection{Concluding remarks}

For sedimentary rocks in general, the range of pore sizes that is typically present requires multiple imaging methods to investigate pores across contrasting scales. The nanoscale size of pores in mudrocks in particular necessitates imaging methods alternative to those typically used for other sedimentary rocks.

In the fine-grained sedimentary systems that are of interest for unconventional resources, much work remains to be done in terms of placing pores into the context of rock history in a manner that that support efforts at prediction It is clear that pore systems in mudrocks undergo 
dramatic alteration in diagenesis, but the basic mechanisms of this modification are not fully understood. Although the basic categories of pores in fine-grained rocks (primary, secondary, inter-, intra-granular) are fully analogous to pores in coarser grained lithologies, porosity evolution in mud and mudrocks may follow rather different pathways as a consequence of the peculiarities of chemical and mechanical processes as expressed at the nanoscale.

In conventional reservoirs new ways of seeing pores and pore walls (colored impregnation, CL-imaging) opened new avenues for quantification that allowed the driving processes of porosity evolution to be modeled accurately. The ability to recognize the meaning and significance of novel observations made with new techniques (e.g., CL) depended greatly upon the store of knowledge and insight built up from application of previous methods (e.g., light microscopy) as no one method holds the key to full understanding. In the fine-grained systems that now draw our attention, empirical understanding is still being built and the fine crystal sizes and compositional complexity of these rocks require techniques to gather observations across a range of scales from the millimeters to nanometers. Knowledge and use of the techniques and approaches described in our review will allow researchers to elucidate the chemical and mechanical controls on porosity evolution in a way that, we hope, can ultimately lead to useful powers of prediction for porosity and related bulk rock properties in fine-grained sedimentary rocks.

\author{
Acknowledgments \\ Over the past 35 years KLM has received support from the National Science Foundation, the \\ Department of Energy, industry consortia at the University of Texas run through the Department
}


of Geological Sciences and the Bureau of Economic Geology, numerous individual petroleum companies, and the Geology Foundation of the Jackson School of Geosciences. MEC would like to acknowledge the support of Devon Energy and the OU Unconventional Shale Gas Consortium. KLM thanks Rob Reed, Rob Lander, Steve Laubach, and Michael DePangher for helpful discussions during preparation of the manuscript. This paper is an outgrowth of a presentation "Void Space Made Real: Imaging Pores in Sedimentary Rocks" invited for a 2013 GSA session planned by Anita Csoma of ConocoPhillips. This paper is authorized by the Director, Bureau of Economic Geology. We thank Review Paper Coordinator Timothy Horscroft for encouraging us to write this paper and an anonymous reviewer for their constructive efforts on behalf of our manuscript. 


\section{Figures}

Figure 1. Primary intergranular pores and intergranular volume (IGV).

A. Quartz-rich sandstone with quartz cement and preserved primary intergranular pores which are filled with a blue plastic resin. Oligocene, France. Plane-polarized light image modified from Milliken et al. (2007).

B. Interpreted view of image A. Surviving intergranular pores are dark blue; pale blue mask cover intergranular quartz cement. Grains are yellow. The volume occupied by the cement and the intergranular pores together constitutes IGV. The IGV at deposition was even greater than the current IGV because compactional strain has figured into the porosity decline.

C. Porous echinoderm grainstone with preserved intergranular pores (filled with a blue plastic resin). Note that compaction has caused local breakage of the cement (yellow arrows), leading to minor rearrangement of the primary porosity. Yellow oval indicates minor secondary grain dissolution porosity. Cretaceous, Mississippi, USA. Plane-polarized light image modified from Milliken and Choh (2011) (calcite is stained pink with alizarin red-S).

D. Interpreted view of image $\mathrm{C}$. The combined volume occupied by the intergranular pores c (darker blue) and the cement (blue mask) together constitutes IGV. The original porosity in this rock was at least as large as the IGV and perhaps greater. Grains are yellow.

Figure 2. Primary intragranular pores. 
A. Primary intragranular pores (filled with a blue plastic resin) within a gastropod fragment partially filled with detrital mud. Right side of gastropod contains a pore caused by a boring organism (red x); whether to classify this pore as "primary intragranular" versus "secondary bioerosion" is a technical debate that bears little on the assigned character of the bulk porosity. Holocene sediment, Jamaica. Planepolarized light image modified from Milliken and Choh (2011).

B. Fusilinid forminifer with chambers (former primary intragranular pores) filled by sparry calcite cement (red x). Permian, West Texas. Plane-polarized light image modified from Milliken and Choh (2011).

Figure 3. Secondary pore types.

A. Secondary intragranular pore filled with blue plastic resin. In addition to surviving remnants of the detrital feldspar, minor amounts of microporous kaolinite ( $\mathrm{Kr}$ ) replace the grain. Additional kaolinite cement $(\mathrm{Kc})$ fills partially fills the intergranular pore space in the lower half of the image. Pennsylvanian, Kentucky. Plane-polarized light image.

B. Interpreted view of image A. Surviving remnants of albitic feldspar are masked in pale purple.

C. Intraclast/foraminifer grainstone with extensive secondary pore development. Permian, West Texas. Plane-polarized light image modified from Milliken and Choh (2011). Calcite is stained pink with alizarin red-S.

D. Interpreted view of image $\mathrm{C}$, based on a digital extraction of blue pixels (pores). Red outlines denote grains. Pores within the grain boundaries are secondary; pores external to the grains are primary intergranular pores. The IGV of this image is equal 
to the total image area minus the grain area. Most of the pores in this sample are not within the IGV.

Figure 4. Grain replacement in which fabrics suggest a tight connection between mineral dissolution and precipitation that leaves little to no associated porosity. In such cases the replacement mineral typically displays euhedral terminations along the contact with the dissolving mineral that suggest a volume-for-volume replacement (Maliva and Siever, 1988).

A. Fe-dolomite replacing detrital albite $(\mathrm{ab})$ in a sandstone. Dolomite has nucleated on a detrital dolomite grain at breaks in the siderite overgrowth. Remnants of the replaced feldspar are seen as gray inclusions scattered through the Fe-dolomite. Back-scattered electron image.

B. Euhedral pyrite (py) replacing a calcitic skeletal fragment in a calcareous mudstone. Back-scattered electron image.

C. Fe-dolomite (purple) replacing Na-rich detrital feldspar (green) in an organic-rich mudstone. Feldspar is also partially replaced by calcite (blue). X-ray map. D. Authigenic albite (ab) replacing carbonate allochems in a calcareous mudstone. Xray map.

Figure 5. Porosity inversion through diagenesis. The complex paragenesis in this sandstone entails substantial dissolution of a portion of the unstable volcanogenic grains (yellow outlines). Cementation has primarily affected primary intergranular pores and includes an early generation of green chlorite cement $(\mathrm{Cc})$ and a later generation of zeolite cement $(\mathrm{Zc})$. Chlorite $(\mathrm{Cr})$ and zeolite $(\mathrm{Zr})$ have also precipitated as grain replacements within space opened by grain dissolution prior to cementation. Thus, grain dissolution has overlapped the 
timing of cement growth, a small portion of the grains dissolving prior to cementation but the greater bulk of dissolution post-dating cementation. A key point here is that the specimen is still recognizably sedimentary, with clear grain and intergrain components, despite the massive alteration. Izu-Bonin Arc, western Pacific. Plane-polarized light image by Kathleen Marsaglia and modified from Milliken et al., 2007.

Figure 6. Extreme diagenetic replacement that obscures the primary fabric. Pores in this sample cannot be readily placed into the context of the original depositional fabric. Yellow outlines are very tentative interpretations of the outer edges of former grains (possible ooids of originally calcitic or aragonitic composition) that have been replaced by euhedral to subhedral dolomite. Dolomite crystals within the interpreted grain volumes are classified as grain replacements and pores within those volumes are secondary. Dolomite outside of the interpreted grain volume is possibly cement and pores within that part of the rock may be surviving intergranular pores. There is no discernible difference however between the dolomite crystals within and without the interpreted grain volumes. In effect, the sedimentary fabric of the rock is very nearly erased by the dolomitization and the pores are best categorized as simply intercrystalline. Vacuoles that appear as brownish microinclusions are intercrystalline pores. Further cementation would ultimately lead to a crystalline fabric that is essentially the same as those of metamorphic carbonate (marble). Permian dolomite, West Texas. Plane-polarized light image modified from Milliken and Choh (2011).

Figure 7. Key technology that enabled the pore categorizations described in Figures 1-6. This method for enabling visualization of the pores is restricted to pores that are larger than 
the thickness of a thin section and to rocks with sufficient permeability to allow impregnation with the colored medium.

Figure 8. Shale samples prepared for SEM.

A. SE image of un-milled broken surface showing possible porosity or simply grain pluckouts indicated by black arrows. A large region of organic matter (OM) crosses the central portion of the image.

B. BSE image of FIB milled surface on same sample as shown in A. Organic matter (OM) is widely dispersed as stringers throughout the sample. Very little porosity in observed (white arrows) suggesting that most of the apparent porosity visible in $\mathrm{A}$ is due to grain pluck-outs.

C. BSE image of FIB milled surface displaying curtaining artifacts (near-vertical grooves most strongly developed on right and left sides of image).

D. BSE image of FIB milled surface showing calcite sputter redeposition (c) in organic matter-hosted pores.

Figure 9. Pore types in fine-grained sediment.

A. Shallowly buried marine mud (Pleistocene) contains primary intergranular pores (red arrows) as well as an abundance of primary intragranular pores within diatom fragments (yellow arrow). Secondary electron image.

B. Pores between K-phyllosilicate grains in a Cretaceous-age calcareous mudrock. Secondary electron image. 
C. A through-going transgranular fracture in a Mississippian phosphatic mudstone. The former pore space is now filled with calcite (c) and quartz (q). The bright phase within the quartz is barite. Back-scattered electron image.

D. Organic-matter hosted pores within organic which itself appears to be pore-filling. Euhedral terminations on crystals (quartz) now surrounded by the organic matter required open pore space at the time they were growing. Hence, paragenetic relationships suggest that the organic matter is some type of residual hydrocarbon and the contained pores are secondary and related to thermal maturation. Back-scattered electron image.

Figure 10. OM-hosted pores within OM filling a secondary pore in a mudrock.

A. In this combined secondary/back-scattered electron image, it is clear that the pores are surrounded by organic matter. But little further interpretation can be obtained. Is the organic matter detrital or diagenetic? Are the pores primary or secondary?

B. X-ray map of the same field of view seen in A. Magnification is somewhat beyond the ideal for this method as indicated by the fuzzy borders on the various regions mapped for individual elements. The fuzziness arises because the interaction volumes for X-ray generation are larger than some of the features being imaged. Yellow maps Kphyllosilicates, dark blue maps calcite, red maps quartz, aqua maps Na-feldspar. The dashed dark blue line marks the outer edge of a detrital feldspar grain. The dotted pale blue line denotes a former secondary pore within the feldspar. Because the organic matter fills a secondary pore it is interpreted as a residual hydrocarbon (RH) phase). The pores within the feldspar are clearly secondary, but it remain uncertain whether these pores are simply residual, un-filled feldspar dissolution pores or pores that arose from thermal decomposition of the residual hydrocarbon. 
Figure 11. Cements in larger primary intragranular pores in mudrocks.

A. Pyrite crystals filling an intact coccosphere in a calcareous ooze. Pleistocene, eastern Mediterranean. Back-scattered electron image of an Ar-ion milled surface.

B. Dark-luminescing sparry calcite cement (cc) filling spaces within bright-luminescing calcified radiolaria and other allochems. Careful inspection reveals the same darkluminescing material also fills spaces between the clay-size carbonate particles that compose most of the sediment. Cold-cathode cathodoluminescence image. Mississippian, Barnett Shale.

Table

Table 1. Imaging methods applied to sedimentary rocks.

References

Ajdukiewicz, J. M., and Lander, R. H., 2010, Sandstone reservoir quality prediction: state of the art: AAPG Bulletin, v. 94, p. 1082-1091.

Allen, D. R., and Chilingarian, G. V., 1975, Mechanics of sand compaction: Developments in Sedimentology, v. 18A, p. 43-78.

American Petroleum Institute, 1998, Recommended Practices for Core Analysis, Washington, D.C., API Exploration and Production Department, Recommended Practice, 236 p. Aplin, A. C., and Macquaker, J. H. S., 2011, Mudstone diversity: Origin and implications for source, seal, and reservoir properties in petroleum systems: AAPG Bulletin, v. 95, p. 2031-2059. 
Aplin, A. C., Matenaar, I. F., McCarty, D. K., and van der Pluijm, B. A., 2006, Influence of mechanical compaction and clay mineral diagenesis on the microfabric and pore-scale properties of deep-water Gulf of Mexico mudstones: Clays and Clay Minerals, v. 54, p. 514-500.

Athy, A. F., 1930, Density, porosity, and compaction of sedimentary rocks: AAPG Bulletin, v. 14, p. 1-24.

Bartholdy, J., Pedersen, J. B. T., and Bartholdy, A. T., 2010, Autocompaction of shallow silty salt marsh clay: Sedimentary Geology, v. 223, p. 310-319.

Bernard, S., Horsfield, B., Schulz, H.-M., Wirth, R., Schreiber, A., and Sherwood, N., 2012a, Geochemical evolution of organic-rich shales with increasing maturity: A STXM and TEM study of the Posidonia Shale (Lower Toarcian, northern Germany): Marine and Petroleum Geology, v. 31, no. 70-89.

Bernard, S., Wirth, R., Schreiber, A., Schulz, H.-M., and Horsfield, B., 2012b, Formation of nanoporous pyrobitumen residues during maturation of the Barnett Shale (Fort Worth Basin). International Journal of Coal Geology, v. 103, no. 3-11.

Bhartia, R., Hug, W. F., Reid, R. D., Salas, E. C., Nealson, K. H., and Lane, A. L., 2008, Deep UV native fluorescence and resonance Raman spectroscopy for life-detection: Geochimica et Cosmochimica Acta, v. 72, no. 12S, p. A80-A80.

Boggs, S., Jr., 2006, Application of cathodoluminescence imaging to the study of sedimentary rocks, Cambridge University Press, 177 p.

Brown, A., 2000, Evaluation of possible gas microseepage mechanisms: AAPG Bulletin, v. 84, p. $1775-1789$. 
Budd, D. A., 2002, The relative roles of compaction and early cementation in the destruction of permeability in carbonate grainstones: a case study from the Paleogene of west-central Florida, U.S.A.: Journal of Sedimentary Research, v. 72, p. 116-128.

Burrus, R. C., Slepkov, A. D., Pegoraro, A. F., and Stolow, A., 2012, Unraveling the complexity of deep gas accumulations with three-dimensional multimodal CARS microscopy: Geology, v. 40, p. 1063-1066.

Chester, J. S., Lenz, S. C., Chester, F. M., and A., L. R., 2004, Mechanisms of compaction of quartz sand at diagenetic conditions: Earth and Planetary Science Letters, v. 220, p. 435451.

Clarkson, C. R., Solano, N., Bustin, R. M., Bustin, A. M. M., Chalmers, G., He, L., Melnichenko, Y. B., Radlinski, A. P., and Blach, T. P., 2013, Pore structure characterization of North American gas shale reservoirs using USANS/SANS, gas adsorption, and mercury intrusion: Fuel, v. 103, p. 606-616.

Cnudde, V., and Boone, M. N., 2013, High-resolution X-ray computed tomography in geosciences: A review of the current technology and applications: Earth-Science Reviews, v. 123, p. 1-17.

Coulson, I. M., 2014, Cathodoluminescence and its application to geoscience, Short Course Series, Volume 45, Mineralogical Association of Canada, p. 182.

Craig, J. R., and Vaughn, D. J., 1994, Ore microscopy and ore petrography, 2nd Edition, New York, Wiley.

Croize, D., Bjorlykke, K., Jahren, J., and Renard, F., 2010, Experimental mechanical and chemical compaction of carbonate sand: Journal of Geophysical Research, v. 115, no. B11, p. B11204-B11204. 
Curtis, C. E., Goergen, E. T., Jernigen, J., Sondergeld, C., and Rai, C., Mapping organic matter distribution on the centimeter scales with nanometer resolution, in Proceedings Unconventional Resources Technology Conference, Denver, Colorado, 2014, SPEAAPG-SEG, URTeC 1922757.

Curtis, M. E., Ambrose, R., Sondergeld, C., and Rai, C., 2011, Transmission and scanning electron microscopy investigation of pore connectivity of gas shales on the nanoscale, North American Unconventional Gas Conference and Exhibition: The Woodlands, Texas, USA, Society of Petroleum Engineers, SPE 144391.

Curtis, M. E., Ambrose, R. J., Sondergeld, C. H., and Rai, C. S., Structural characterizatino of gas shales on the micro- and nano-scales, in Proceedings Canadian Unconventional Resources and International Petroleum Conference, Calgary, Alberta, 2010, Society of Petroleum Engineers, CUSG/SPE 137693.

Day-Stirrat, R. J., Dutton, S. P., Milliken, K. L., Loucks, R. G., Aplin, A. C., Hillier, S., and van der Pluijm, B. A., 2010, Fabric anisotropy induced by primary depositional variations in the silt:clay ratio in two fine-grained slope fan complexes: Texas Gulf Coast and northern North Sea: Sedimentary Geology, v. 226, no. 1-4, p. $42-53$.

Day-Stirrat, R. J., Flemings, P. B., You, Y., Aplin, A. C., and van der Pluijm, B. A., 2012, The fabric of consolidation in Gulf of Mexico mudstones: Marine Geology, v. 295-298, p. 7785.

de Boer, R. B., 1977, On the thermodynamics of pressure solution--interaction between chemical and mechanical forces: Geochimica et Cosmochimica Acta, v. 41, p. 249-256. 
de la Torre, J. R., Goebel, B. M., Friedmann, E. I., and Pace, N. R., 2003, Microbial diversity of cryptoendolithic communties from the McMurdo Dry Valleys, Antarctica: Applied and Environmental Microbiology, v. 69, p. 3858-3867.

Desbois, G., Urai, J. L., and Kukla, P. A., 2009, Morphology of the pore space in claystones-evidence from BIB/FIB ion beam sectioning and cryo-SEM observations: eEarth Discussions, v. 4, p. 1-19.

Dewhurst, D. N., and Aplin, A. C., 1999, Influence of clay fraction on pore-scale properties and hydraulic conductivity of experimentally compacted mudstones: Journal of Geophysical Research, v. 104, no. B12, p. 29261-29274.

Doveton, J. H., 2014, Principles of Mathematical Petrophysics, New York, Oxford University Press, 248 p.

Ehrenberg, S. N., 1989, Assessing the relative importance of compaction processes and cementation to reduction of porosity in sandstones: discussion: American Association of Petroleum Geologists Bulletin, v. 73, p. 1274-1276.

,- 1995, Measuring sandstone compaction from modal analyses of thin sections: How to do it and what the results mean: Journal of Sedimentary Research, v. A65, p. 369-379.

Ehrenberg, S. N., and Walderhaug, O., 2015, Preferential calcite cementation in macropores in microporous limestones: Journal of Sedimentary Research, v. 85, p. 780-793.

Ehrlich, R., Crabtree, S. J., Horkorwitz, K. O., and Horkowittz, J. P., 1991, Petrography and reservoir physics I: Objective classification of reservoir porosity: AAPG Bulletin, v. 75, p. $1547-1562$. 
Eliyahu, M., Emmanuel, S., Day-Stirrat, R. J., and Macaulay, C. I., 2015, Mechanical properties of organic matter in shales mapped at the nanometer scale: Marine and Petroleum Geology, v. 59, p. 294-304.

Elphick, S. C., Graham, C. M., Walker, F. D. L., and Holness, M. B., 1991, The application of SIMS ion imaging techniques in the experimental study of fluid-mineral interactions: Mineralogical Magazine, v. 55, p. 347-356.

Emmanuel, S., Ague, J. J., and Walderhaug, O., 2010, Interfacial energy effects and the evolution of pore size distributions during quartz precipitation in sandstone: Geochimica Cosmochimica Acta, v. 74, p. 3539-3552.

Emmanuel, S., and Day-Stirrat, R. J., 2012, A framework for quantifying size dependent deformation of nano-scale pores: Journal of Applied Geophysics, v. 86, p. 29-35.

Etris, E., Brumfield, D., Ehrlich, R., and Crabtree, S., 1988, Relations between pores, throats and permeability: A petrographic/physical analysis of some carbonate grainstones and packstones: Carbonates and Evaporites, v. 3, no. 1, p. 17-32.

Fabricius, I. L., 2007, How depositional texture and diagenesis control petrophysical and elastic properties of samples from five North Sea chalk fields, in Rogen, B., and Gommesen, L., eds., Petroleum Geoscience, Volume 13: United Kingdom, Geological Society Publishing House for EAGE (European Association of Geoscientists \& Engineers : London, United Kingdom, p. 95-81.

Fedo, C. M., Young, G. M., Nesbitt, H. W., and Hanchar, J. M., 1997, Potassic and sodic metasomatism in the Southern Province of the Canadian Shield; evidence from the Paleoproterozoic Serpent Formation: Precambrian Research, v. 84, p. 17-36. 
Fishman, N. S., Hackley, P. C., Lowers, H. A., Hill, R. J., Egenhoff, S. O., Eberl, D. D., and Blum, A. E., 2012, The nature of porosity in organic-rich mudstones of the Upper Jurassic Kimmeridge Clay Formation, North Sea, offshore United Kingdom: International Journal of Coal Geology, v. 103, p. 32-50.

Folk, R. L., 1965, Henry Clifton Sorby (1826 -1908) founder of petrography: Journal of Geological Education, v. 13, p. 43.

Fothergill, C. A., 1955, The cementation of oil reservoir sands and its origin: Proceedings World Petroleum Congress, v. 59, p. 301-314.

Fyfe, W. S., and Thompson, A. B., 1978, Fluids in the Earth's Crust: Their Significance, tectonic, and chemical transport processes, New York, Elsevier Scientific Publishing Company, $383 \mathrm{p}$.

Gale, J. F. W., Lander, R. H., Reed, R. M., and Laubach, S. E., 2010, Modeling fracture porosity evolution in dolostone: Journal of Structural Geology, v. 32, p. 1201-1211.

Gale, J. F. W., Laubach, S. E., Olson, J. E., Eichhubl, P., and Fall, A., 2014, Natural fractures in shale: A review and new observations: AAPG Bulletin, v. 98, p. 2165-2216.

Gilbert, C. M., 1949, Cementation of some California Tertiary reservoir sands: Journal of Geology, v. 57, no. 1, p. 1-17.

Giles, M. R., Indrelid, S. L., and James, D. M. D., 1998, Compaction -- the great unknown in basin modelling: Geological Society, London, Special Publications, v. 141, no. 1, p. 1543.

Goergen, E. T., Curtis, M. E., Jernigen, J., Sondergeld, C., and Rai, C., Integrated petrophysical properties and multi-scales SEM microstructural characterization, in Proceedings 
Unconventional Resources Technology Conference Denver, Colorado, 2014, SPEAAPG-SEG, p. URTeC 1922739.

Goff, J. C., and Williams, B. P. J., 1987, Fluid Flow in Sedimentary Basins and Aquifers, Geological Society Special Publication, Volume 34, Blackwell Scientific Publications, p. 230.

Goldstein, A., Jr., 1948, Cementation of Dakota sandstone of the Colorado Front Range: Journal of Sedimentary Petrology, v. 18, p. 108-125.

Haddad, S. C., Worden, R. H., Prior, D. J., and Smalley, P. C., 2006, Quartz Cement in the Fontainebleau Sandstone, Paris Basin, France: Crystallography and Implications for Mechanisms of Cement Growth: Journal of Sedimentary Research, v. 76, no. 2, p. 244256.

Hayes, J. B., 1979, Sandstone diagenesis---the hole truth, in Scholle, P. A., and Schluger, P. R., eds., Aspects of Diagenesis, Volume 26: Tulsa, Oklahoma, Society of Economic Paleontologists and Mineralogists, p. 127-139.

Heald, M. T., and Larese, R. E., 1974, Influence of coatings on quartz cementation: Journal of Sedimentary Petrology, v. 44, p. 1269-1274.

Heaney, P. J., Vicenzi, E. P., Giannuzzi, L. A., and Livi, K. J. T., 2001, Focused ion beam milling: A method of site-specific sample extractionm for microanalysis of Earth and planetary materials: American Mineralogist, v. 86, p. 1094-1099.

Heath, J. E., Dewers, T. A., McPherson, B. J. O. L., Petrusak, R., Chidsey, T. C., Jr., Rinehart, A. J., and Mozley, P. S., 2011, Pore networks in continental and marine mudstones; characteristics and controls on sealing behavior: Geosphere, v. 7, no. 2, p. 429-454. 
Howarth, R. W., Santoro, R., and Ingraffea, A., 2011, Methane and greenhouse-gas footprint of natural gas from shale formations: Climatic Change, v. 106, p. 679-690.

Huc, A. Y., Nederlof, P., Debarre, R., Carpentier, B., Boussafir, M., Laggoun-Defarge, F., Lenail-Chouteau, A., and Bordas-Le Floch, N., 2000, Pyrobitumen occurrence and formation in a Cambro-Ordovician sandstone reservoir, Fahud salt basin, North Oman: Chemical Geology, v. 168, no. 1-2, p. 99-112.

Jarvie, D. M., Hill, R. J., Ruble, T. E., and M., P. R., 2007, Unconventional shale-gas systems: The Mississippian Barnett Shale of north-central Texas as one model for thermogenic shale-gas assessment: AAPG Bulletin, v. 91, p. 475-499.

Javadpour, F., Farshi, M. M., and Amrein, M., 2012, Atomic-force microscopy: A new tool for gas-shale characterization: Journal of Canadian Petroleum Technology, v. July 2012, p. 236-243.

Johnson, R. H., 1920, The cementation process in sandstone: American Association of Petroleum Geologists Bulletin, v. 4, p. 33-35.

Kanitpanyacharoen, W., Kets, F. B., Wenk, H.-R., and Wirth, R., 2012, Preferred orientation and microstructure in the Posidonia Shale in relation to different degrees of thermal maturity: Clays and Clay Minerals, v. 60, p. 315-329.

Kastner, M., and Siever, R., 1979, Low temperature feldspars in sedimentary rocks: American Journal of Science, v. 279, p. 435-479.

Katsube, T. J., and Williamson, M. A., 1994, Effects of diagenesis on shale nano-pore structure and implications for sealing capacity: Clay Minerals, v. 29, p. 451-461. 
Keller, L. M., Holzer, L., Wepf, R., and Gasser, P., 2011a, 3D geometry and topology of pore pathways in Opalinus Clay; implications for mass transport: Applied Clay Science, v. 52, no. $1-2$, p. $85-95$.

Keller, L. M., Holzer, L., Wepf, R., Gasser, P., Muench, B., and Marschall, P., 2011b, On the application of focused ion beam nanotomography in characterizing the 3D pore space geometry of Opalinus Clay: Physics and Chemistry of the Earth, v. 36, no. 17-18, p. $1539-1544$.

Kennedy, A. D., 1993, Water as a limiting factor in the Antarctic terrestrial environment--a biogeographical synthesis: Arctic and Alpine Research, v. 25, p. 308-315.

Ketcham, R. A., and Carlson, W. D., 2001, Acquistion, optimization, and interpretation of X-ray computed tomographic imagery: applications to the geosciences: Computers \& Geosciences, v. 27, p. 381-400.

Kim, J.-W., Bryant, W. R., Watkins, J. S., and Tieh, T. T., 1999, Electron microscopic observations of shale diagenesis, offshore Louisiana, USA, Gulf of Mexico: Geo-Marine Letters, v. 18, p. 234-240.

King, H. E., Jr., R., E. A. P., Walters, C. C., Kliewer, C. E., Ertas, D., and Huynh, C., 2015, Pore architecture and connectivity in gas shale: Energy and Fuels, v. 29, p. 1375-1390.

Kopf, A., and Behrmann, J. H., 1997, Fabric evolution and mechanisms of diagenesis in finegrained sediments from the Kita-Yamato Trough, Japan Sea: Journal of Sedimentary Research, v. 67, p. 590-600.

Krinsley, D., Pye, K., Boggs, S., Jr., and Tovey, N. K., 1998, Backscattered Scanning Electron Microscopy and Image Analysis of Sediments and Sedimentary Rocks, New York, Cambridge University Press, 193 p. 
Kuhlman, K. R., Conrad, P. G., Kelly, T. F., Miller, M. K., Evans, N. D., Dunn, D. N., and Hull, R., 2001, New techniques for nanoanalysis and nanogeology: Abstracts with Programs Geological Society of America, v. 33, no. 6, p. 450-450.

Land, L. S., and Macpherson, G. L., 1992, Origin of saline formation waters, Cenozoic section, Gulf of Mexico sedimentary basin: American Association of Petroleum Geologists Bulletin, v. 76, p. 1344-1362.

Land, L. S., Milliken, K. L., and McBride, E. F., 1987, Diagenetic evolution of Cenozoic sandstones, Gulf of Mexico sedimentary basin: Sedimentary Geology, v. 50, p. 195-225.

Lander, R. H., Larese, R. H., and Bonnell, L. M., 2008, Toward more accurate quartz cement models: The importance of euhedral versus noneuhedral growth rates: American Association Petroleum Geologists Bulletin, v. 92, p. 1537-1563.

Lander, R. H., and Laubach, S. E., 2015, Insights into rates of fracture growth and sealing from a model for quartz cementation in fractured sandstones: Geological Society of America Bulletin, v. 127, p. 516-538.

Lander, R. H., and Walderhaug, O., 1999, Predicting porosity through simulating sandstone compaction and quartz cementation: American Association of Petroleum Geologists Bulletin, v. 83, p. 433-449.

Laubach, S. E., Eichhubl, P., Hilgers, C., and Lander, R. H., 2010, Structural diagenesis: Journal of Structural Geology, v. 32, no. 12, p. 1866-1872.

Laubach, S. E., and Milliken, K. L., New fracture characterization techniques for siliciclastic rocks, in Proceedings Second North American Rock Mechanics Symposium1996, Balkema, p. 1209-1213. 
Lee, M. R., 2010, Transmission electron microscopy (TEM) of Earth and planetary materials: A review: Mineralogical Magazine, v. 74, p. 1-27.

Lehner, F. K., 1995, A model for intergranular pressure solution in open systems: Tectonophysics, v. 245, p. 153-170.

Lerbekmo, J. F., 1961, Porosity reduction in Cretaceous sandstones of Alberta: Journal of the Alberta Society of Petroleum Geologists, v. 9, no. 6, p. 192-199.

Lindquist, S. J., 1977, Secondary porosity development and subsequent reduction, overpressured Frio Formation sandstone (Oligocene), South Texas: Gulf Coast Associations of Geological Societies Transactions, v. 27, p. 99-107.

Lockwood, W. N., 1950, Impregnating sandstone speciments with thermosetting plastics for study of oil-bearing formations: AAPG Bulletin, v. 34, p. 2061-2067.

Loomis, J. L., and Crossey, L. J., 1997, Diagenesis in a cyclic, regressive siliciclastic sequence: The Point Lookout Sandstone, Sand Juan Basin, Colorado, in Crossey, L. J., Loucks, R. G., and Totten, M. W., eds., Siliciclastic Diagenesis and Fluid Flow: Concepts and Applications, Volume 55: Tulsa, Oklahoma, Society for Sedimentary Geology, p. 23-36.

Loucks, R. G., and Reed, R. M., 2014, Scannning-electron-microscope petrographic evidence for distinguishing organic-matter pores associated with depositional organic matter versus migrated organic matter: GCAGS Journal, v. 3, p. 51-60.

Loucks, R. G., Reed, R. M., Ruppel, S. C., and Jarvie, D. M., 2009, Morphology, genesis, and distribution of nanometer-scale pores in mudstones of the Mississippian Barnett Shale: Journal of Sedimentary Research, v. 79, p. 848-861.

Lucia, F. J., 1995, Rock-fabric/petrophysical classification of carbonate pore space for reservoir characterization: AAPG Bulletin, v. 79, no. 9, p. 1275-1300. 
Luffel, D. L., Guidry, F. K., and Curtis, J. B., 1996, Development of Laboratory and Petrophysical Techniques for Evaluating Shale Reservoirs: Report No. GRI-95/0496 (October 1986-September 1993) Gas Research Institute, 301 p.

Lundegard, P. D., 1992, Sandstone porosity loss--a 'big picture' view of the importance of compaction: Journal of Sedimentary Petrology, v. 62, p. 250-260.

Luxmoore, R. J., 1981, Micro-, Meso-, and Macroporosity of Soil: Soil Sci. Soc. Am. J., v. 45, no. 3, p. 671-672.

Machel, H. G., and Anderson, J. H., 1989, Pervasive subsurface dolomitization of the Nisku Formation in central Alberta: Journal of Sedimentary Petrology, v. 59, no. 6, p. 891-911. Macquaker, J. H. S., Taylor, K. G., Keller, M., and Polya, M., 2014, Compositional controls on early diagenetic pathways in fine-grained sedimentary rocks: Implications for predicting unconventional reservoir attributes of mudstones: AAPG Bulletin, v. 98, p. 587-603.

Makowitz, A., and Milliken, K. L., 2003, Quantification of brittle deformation in burial compaction, Frio and Mt. Simon sandstones: Journal of Sedimentary Petrology, v. 73, p. 999-1013.

Makowitz, A., and Sibley, D. F., 2001, Crystal growth mechanisms of quartz overgrowths in a Cambrian quartz arenite: Journal of Sedimentary Research, v. 71, p. 809-816.

Maliva, R. G., and Siever, R., 1988, Diagenetic replacement controlled by force of crystallization: Geology, v. 16, p. 688-691.

Maxwell, J. C., 1960, Experiments on compaction and cementation of sand, in Griggs, D. T., and Handin, J., eds., Rock Deformation, Volume 79, Geological Society of America, p. 105132. 
McBride, E. F., 1977, Secondary porosity--importance in sandstone reservoirs in Texas: Gulf Coast Association of Geological Societies Transactions, v. 27, p. 121-122.

Melzer, S. A., and Budd, D. A., 2008, Retention of high permeability during shallow burial (300 to $500 \mathrm{~m}$ ) of carbonate grainstones: Journal of Sedimentary Research, v. 78, p. 548-561.

Merino, E., Nahon, D., and Wang, Y., 1993, Kinetics and mass transfer of pseudomorphic replacement: Application to replacement of parent minerals and kaolinite by $\mathrm{Al}, \mathrm{Fe}$, and Mn oxides during weathering: American Journal of Science, v. 293, p. 135-155.

Mille, G., Guiliano, M., and Kister, J., 1988, Analysis and evolution of coals; UV fluorescence spectroscopy study (demineralized coals-oxidized coals): Organic Geochemistry, v. 13, no. 4-6, p. 947-952.

Milliken, K. L., 1989, Petrography and composition of authigenic feldspars, Oligocene Frio Formation, South Texas: Journal of Sedimentary Petrology, v. 59, p. 361-374.

Milliken, K. L., 1992, Chemical behavior of detrital feldspars in mudrocks versus sandstones, Frio Formation (Oligocene), South Texas: Journal of Sedimentary Petrology, v. 62, p. $790-801$.

Milliken, K. L., 2003, Diagenesis, in Middleton, G. V., Church, M. J., Coniglio, M., Hardie, L. A., and Longstaffe, F. J., eds., Encyclopedia of Sediments and Sedimentary Rocks: Dordrecht, Kluwer Academic Publishers, p. 214-219.

Milliken, K. L., 2004, Late diagenesis and mass transfer in sandstone-shale sequences, in Mackenzie, F. T., ed., Sediments, Diagenesis, and Sedimentary Rocks, Volume 7: Oxford, Elsevier-Pergamon, p. 159-190.

Milliken, K. L., 2014, A compositional classification for grain assemblages in fine-grained sediments and sedimentary rocks: Journal of Sedimentary Research, v. 84, p. 1185-1199. 
Milliken, K. L., and Choh, S.-J., 2011, Carbonate Petrology: An Interactive Petrography Tutorial, v. 1.0, Discovery Series: Tulsa, Oklahoma, American Association of Petroleum Geologists.

Milliken, K. L., Choh, S.-J., and McBride, E. F., 2007, Sandstone Petrology: A Tutorial Petrographic Image Atlas, v. 2.0, Discovery Series: Tulsa, Oklahoma, American Association of Petroleum Geologists.

Milliken, K. L., and Day-Stirrat, R. J., 2013, Cementation in mudrocks: Brief review with examples from cratonic basin mudrocks, in Chatellier, J.-Y., and Jarvie, D. M., eds., Critical Assessment of Shale Resource Plays, Volume 103: Tulsa, Oklahoma, USA, American Association of Petroleum Geologists, p. 133-150.

Milliken, K. L., Esch, W. L., Reed, R. M., and Zhang, T., 2012, Grain assemblages and strong diagenetic overprinting in siliceous mudrocks, Barnett Shale (Mississippian), Fort Worth Basin, Texas, U.S.A.: AAPG Bulletin, v. 96, p. 1553-1578.

Milliken, K. L., Ko, L., Pommer, M., and Marsaglia, K. M., 2014, SEM petrography of eastern Mediterranean sapropels: Analogue data for assessing organic matter in oil and gas shales: Journal of Sedimentary Research, v. 84, p. 961-974.

Milliken, K. L., Land, L. S., and McBride, E. F., 1989, Numerical assessment of dissolution versus replacement in the subsurface destruction of detrital feldspars, Oligocene Frio Formation, South Texas: Journal of Sedimentary Petrology, v. 59, p. 740-757.

Milliken, K. L., Mack, L. E., and Land, L. S., 1994, Elemental mobility in sandstones during burial: Whole-rock chemical and isotopic data, Frio Formation, South Texas: Journal of Sedimentary Research, v. A64, p. 788-796. 
Milliken, K. L., and Reed, R. M., 2010, Multiple causes of diagenetic fabric anisotropy in weakly consolidated mud, Nankai accretionary prism, IODP Expedition 316: Journal of Structural Geology, v. 32, no. 12, p. 1887-1898.

Milliken, K. L., Rudnicki, M., Awwiller, D. N., and Zhang, T., 2013, Organic matter-hosted pore system, Marcellus Formation (Devonian), Pennsylvania, USA: AAPG Bulletin, v. 97, p. 177-200.

Moller, L. N. N., and Friis, H., 1999, Petrographic evidence for hydrocarbon migration in Lower Cambrian sandstones, Bornholm, Denmark: Bulletin of the Geological Society of Denmark, v. 44, Part 2, p. 117-127.

Mondol, N. H., Bjorlykke, K., Jahren, J., and Hoeg, K., 2007, Experimental mechanical compaction of clay mineral aggregates--Changes in physical propeties of mudstones during burial: Marine and Petroleum Geology, v. 24, p. 289-311.

Montgomery, S. L., Jarvie, D. M., Bowker, K. A., and Pollastro, R. M., 2005, Mississippian Barnett Shale, Fort Worth Basin, north-central Texas: Gas-shale play with multi-trillion cubic foot potential: American Association of Petroleum Geologists Bulletin, v. 89, p. $155-175$.

Morad, S., Ketzer, J. M., and De Ros, L. F., 2000, Spatial and temporal distribution of diagenetic alterations in siliciclastic rocks: implications for mass transfer in sedimentary basins: Sedimentology, v. 47 (Supplement 1), p. 95-120.

Murray, R. C., 1960, Origin of porosity in carbonate rocks: Journal of Sedimentary Petrology, v. 30, no. 1 , p. 59-84. 
Nedkvitne, T., Karlsen, D. A., Bjorlykke, K., and Larter, S. R., 1993, Relationship between resrvoir diagenetic evolution and petroleum empblacmenet in the Ula Field, North-Sea: Marine and Petroleum Geology, v. 10, p. 255-270.

Nelson, P. H., 2009, Pore throat sizes in sandstones, tight sandstones, and shales: AAPG Bulletin, v. 93, p. 329-340.

Nesse, W. D., 2013, Introduction to Optical Mineralogy, New York, Oxford University Press, $361 \mathrm{p}$.

Nieto, F., Ortega-Huertas, M., Peacor, D. R., and Arostegui.J., 1996, Evolution of illite-smectite from early diagenesis through incipient metamorphis in sediments of the BasqueCantabrian Basin: Clays and Clay Minerals, v. 44, p. 303-323.

Nole, M., Daigle, H., Milliken, K. L., and Prodanovic, M., in review, A method for estimating microporosity of fine-grained sediments and sedimentary rocks via SEM image analysis.

O'Brien, N. R., and Slatt, R. M., 1990, Argillaceous Rock Atlas, New York, Springer-Verlag, $141 \mathrm{p}$.

Oertel, G., 1983, The relationship of strain and preferred orientation of phyllosilicate grains in rocks-a review: Tectonophysics, v. 100, p. 413-447.

Ohfuji, H., Boyle, A. P., Prior, D. J., and Rickard, D., 2005, Structure of framboidal pyrite: An electron back-scatter diffraction study: American Mineralogist, v. 90, p. 1693-1704.

Parnell, J., 1994, Geofluids: Origin, Migration, and Evolution of Fluids in Sedimentary Basins, Special Publication, Volume 78, Geological Society of London, p. 372.

Passey, Q. R., Bohacs, K. M., Esch, W. L., Kimentidis, R., and Sinha, S., 2010, From oil-prone source rock to gas-producing shale reservoir--Geologic and petrogphysical characterization in unconventional shale-gas reservoirs, CPS/SPE International Oil \& Gas 
Conference and Exhibition: Beijing, China, Society of Petroleum Engineers, SPE 121250.

Paxton, S. T., Szabo, J. O., Adjukiewicz, J. M., and Klimentidis, R. E., 2002, Construction of an intergranular volume compaction curve for evaluating and predicting compaction and porosity loss in rigid-grain sandstone reservoirs: American Association of Petroleum Geologists Bulletin, v. 86, p. 2047-2067.

Pearson, F. J., 1999, What is the porosity of a mudrock?, in Aplin, A. C., Fleet, A. J., and Macquaker, J. H. S., eds., Muds and Mudstones: Physical and Fluid-flow Properties, Volume 158, Geologial Society, London, p. 9-22.

Petford, N., Davidson, G., and Miller, J. A., 1999, Pore structure determination using confocal scanning laser microscopy: Physics and Chemistry of the Earth. Part A: Solid Earth and Geodesy, v. 24, no. 7, p. 563-567.

Pettijohn, F. J., 1941, Persistence of heavy minerals with geologic age: Journal of Geology, v. 49, p. 612-625.

Phaneuf, M. W., 2005, FIB for material science applications: A review, in Giannuzzi, L. A., and Stevie, F. A., eds., Introduction to Focused Ion Beams: Instrumentation, Theory, Techniques, and Practice: New York, Springer, p. 143-172.

Pittman, E. D., 1979, Porosity, diagenesis, and productive capability of sandstone reservoirs, in Scholle, P. A., and Schluger, P. R., eds., Aspects of Diagenesis, Volume 26: Tulsa, Oklahoma, Society of Economic Paleontologists and Mineralogists, p. 159-174.

Pittman, E. D., and Larese, R. E., 1991, Compaction of lithic sands: experimental results and applications: American Association of Petroleum Geologists Bulletin, v. 75, p. 12791299. 
Prasad, M., Applications of scanning acoustic microscopy to reservoir rocks, in Proceedings Society of Exploration Geophysics 67th Annual International Meeting1997, p. 10191022.

Pushie, M. J., Pratt, B. R., MacDonald, T. C., George, G. N., and Pickering, I. J., 2014, Evidence for biogenic copper (hemocyanin) in the Middle Cambrian arthropod Marella from the Burgess Shale: Palaios, v. 29, no. 512-524.

Radlinski, A. P., 2006, Small-angle neutron scattering and the microstructure of rocks: Reviews in Mineralogy and Geochemistry, v. 63, p. 363-397.

Reed, S. J. B., 1996, Electron microprobe analysis and scanning electron microscopy in geology, Cambridge, Cambridge University Press, 201 p.

Ruppert, L. F., Sakurovs, R., Blach, T. P., He, L., Melinchenko, Y. B., Mildner, D. F. R., and Lacantar-Lopez, L., 2013, A USANS/SANS study of the accessibility of pores in the Barnett Shale to methane and water: Energy and Fuels, v. 27, p. 772-779.

Schmidt, V., and McDonald, D. A., 1979a, The role of secondary porosity in the course of sandstone diagenesis, in Scholle, P. A., and Schluger, P. R., eds., Aspects of Diagenesis, Volume 26: Tulsa, Oklahoma, Society of Economic Paleontologists and Mineralogists, p. 175-207.

Schmidt, V., and McDonald, D. A., 1979b, The role of secondary porosity in the course of sandstone diagenesis, in Scholle, P. A., and Schluger, P. R., eds., Aspects of Diagenesis, Volume 26: Tulsa, Oklahoma, Society of Economic Paleontologists and Mineralogists, p. 175-208. 
Schneider, J., Flemings, P. B., Day-Stirrat, R. J., and Germaine, J. T., 2011, Insights into porescale controls on mudstone permeability and compressibility through re-sedimentation experiments: Geology, v. 39, p. 1011-1014.

Scholle, P. A., and Ulmer-Scholle, D. S., 2003, A Color Guide to the Petrography of Carbonate Rocks: Grains, Textures, Porosity, Diagenesis, Tulsa, Oklahoma, American Association of Petroleum Geologists, Memoir, 474 p.

Schön, J., 2015, Physical Properties of Rocks: Fundamentals and Principles of Petrophysics, Amsterdam, Netherlands, Elsevier, Developments in Petroleum Science, v. 65.

Seyedolali, A., Torley, R. F., Krinsley, D., Boggs, S., Jr., and Wagner, L. E., 1994, Threedimensional, high-resolution light microscopy; a new geological tool: Journal of Geological Education, v. 42, no. 5, p. 476-480.

Sippel, R. F., 1968, Sandstone petrology, evidence from luminescence petrography: Journal of Sedimentary Petrology, v. 38, p. 530-554.

Smosna, R., 1989, Compaction law for Cretaceous sandstones of Alaska's North Slope: Journal of Sedimentary Petrology, v. 59, p. 572-584.

Sondergeld, C., Newsham, K. E., Comiski, J. T., Rice, M. C., and Rai, C. S., Petrophysical considerations in evaluating and producting shale gas, in Proceedings SPE Unconventional Gas Conference, Pittsburgh, Pennsylvania, USA, 2010a, Society of Petroleum Engineers, SPE 131768.

Sondergeld, C. H., Ambrose, R. J., Rai, C. S., and Moncrieff, J., 2010b, Micro-structural studies of gas shales, SPE Unconventional Gas Conference, Volume SPE 131771: Pittsburgh, Pennsylvania, USA, Society of Petroleum Engineers.

Stach, E., and al., e., 1982, Coal Petrology, Berlin, Gebruder Borntraeger, 535 p. 
Stanton, G. D., 1977, Secondary porosity in sandstones of the lower Wilcox (Eocene), Karnes County: Gulf Coast Association of Geological Societies Transactions, v. 27, p. 147-207.

Stumm, W., and Morgan, J. J., 1996, Aquatic Chemistry. Chemical Equilibria and Rates in Natural Waters, Wiley-Interscience, $1022 \mathrm{p}$.

Summerson, C. H., 1976, Sorby on Sedimentology: A Collection of Papers from 1851 - 1908:

Miami, Florida, Division of Marine Geology and Geophysics, University of Miami, , p. 225.

Szabo, J. O., and Paxton, S. T., 1991, Intergranular volume (IGV) decline curves for evaluating and predicting compaction and porosity loss in sandstones (abs.):: AAPG Bulletin, v. 75, no. 3 , p. 678 .

Taylor, J. M., 1950, Pore space reduction in sandstone: AAPG Bulletin, v. 34, p. 701-716.

Taylor, T., Stancliffe, R., Macaulay, C., and Hathon, L. A., 2004, High temperature quartz cementation and timing of hydrocarbon accumulation in the Jurassic Norphlet Sandstone, offshore Gulf of Mexico, USA, in Cubitt, J. M., England, W. A., and Larter, S. R., eds., Understanding Petroleum Reservoirs; towards an integrated reservoir engineering and geochemical approach, Volume 237: London, United Kingdom, Geological Society of London, p. 257-278.

Taylor, T. R., Giles, M. R., Hathon, L. A., Diggs, T. N., Braunsdorf, N. R., Birgilia, G. V., Kittridge, M. G., Macauley, C. I., and Espejo, I. S., 2010, Sandstone diagenesis and reservoir quality prediction: Models, myths, and reality: AAPG Bulletin, v. 94, p. 10931132. 
Taylor, T. R., Kittridge, M. G., Winefield, P., Bryndzia, T., and Bonnell, L. M., 2015, Reservoir quality and rock property modeling--Triassic and Jurassic sandstones, greater Shearwater area, UK Central North Sea: Marine and Petroleum Geology, v. 65, p. 1-21.

Tiab, D., and Donaldson, E. C., 2015, Petrophysics: Theory and Practice of Measuring Reservoir Rock and Fluid Properties, Amsterdam, Gulf Professional Publishing, 894 p.

Tissot, B. P., and Welte, D. H., 1984, Petroleum Formation and Occurrence, Berlin, Springer Verlag, $699 \mathrm{p}$.

Tobin, R. C., McClain, T., Lieber, R. B., Ozkan, A., Banfield, L. A., Marchand, A. M. E., and McRae, L. E., 2010, Reservoir quality modeling of tight-gas sands in Wamsutter field: Integration of diagenesis, petroleum systems, and production data: AAPG Bulletin, v. 94, p. $1229-1266$.

Van Geet, M., Swennen, R., and Wevers, M., 2000, Quantitative analysis of reservoir rocks by microfocus X-ray computerised tomography: Sedimentary Geology, v. 132, p. 25-36.

Velde, B., 1996, Compaction trends of clay-rich deep sea sediments: Marine Geology, v. 133, no. 3-4, p. 193-201.

Walters, C. C., Kliewer, C. E., Awwiller, D. N., Rudnicki, M., Passey, Q. R., and Lin, M. W., 2014, Influence of turbostratic carbon nanostructures on electrical conductivity in shales: International Journal of Coal Geology, v. 122, no. 105-109.

Watt, G. R., Griffin, B. J., and Kinny, P. D., 2000, Charge contrast imaging of geological materials in the environmental scanning electron microscope: American Mineralogist, v. 85, p. $1785-1794$.

Weller, J. M., 1959, Compaction in sediments: American Association of Petroleum Geologists Bulletin, v. 43, p. 273-310. 
White, S. H., Shaw, H. F., and Huggett, J. M., 1984, The use of back-scattered electron imaging for the petrographic study of sandstones and shales: Journal of Sedimentary Petrology, v. 54, p. 487-494.

Wilkinson, D. G., 1900, A method to render visible the porosity of rocks in thin section: Amateur Geologist, v. 8, no. 2, p. 30-31.

Wilson, M. D., 1994, Reservoir Quality Assessment and Prediction in Clastic Rocks, SEPM Short Course, Volume 30, Society of Economic Paleontologists and Mineralogists, p. 432.

Wolela, A. M., and Gierlowski-Kordesch, E. H., 2007, Diagenetic history of fluvial and lacustrine sandstones of the Hartford Basin (Triassic-Jurassic), Newark Supergroup, USA: Sedimentary Geology, v. 197, no. 1-2, p. 99-126.

Yang, Y., and Aplin, A. C., 2007, Permeability and petrophysical properties of 30 natural mudstones, Journal of Geophysical Research, Volume 112: p. B03206-B03206.

Yanguas, J. E., and Dravis, J. J., 1985, Blue fluorescent dye technique for recognition of microporosity in sedimentary rocks: Journal of Sedimentary Petrology, v. 55, p. 600-602.

Zdravkov, B., Čermák, J., Šefara, M., and Janků, J., 2007, Pore classification in the characterization of porous materials: A perspective: Central European Journal of Chemistry, v. 5, no. 2, p. 385-395.

Zeszotarski, J. C., Chromik, R. R., Vinci, R. P., Messmer, M. C., Michels, R., and Larsen, J. W., 2004, Imaging and mechanical property measurments of kerogen via nanoindentation: Geochimica Cosmochimica Acta, v. 68, p. 4113-4119. 

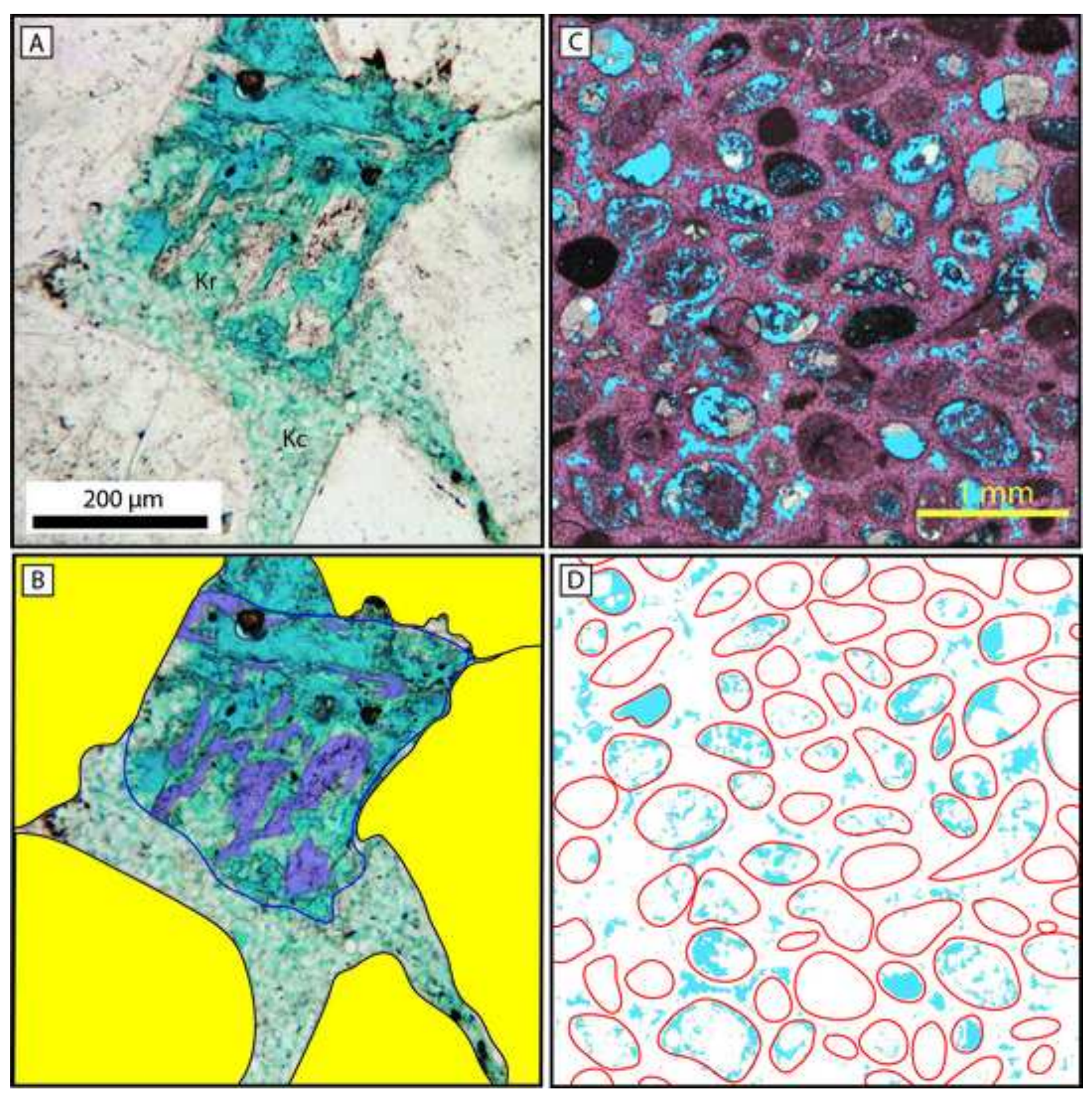

Figure 3

3

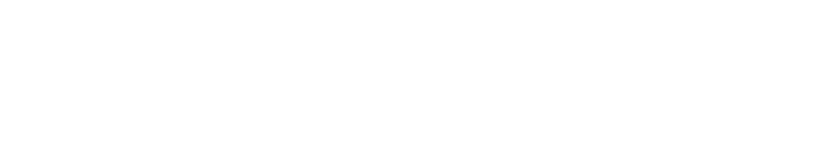

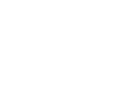

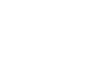

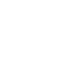

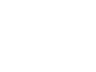

-

. .

\section{. \\ .} . .

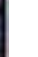

$$
\text { . }
$$
. 


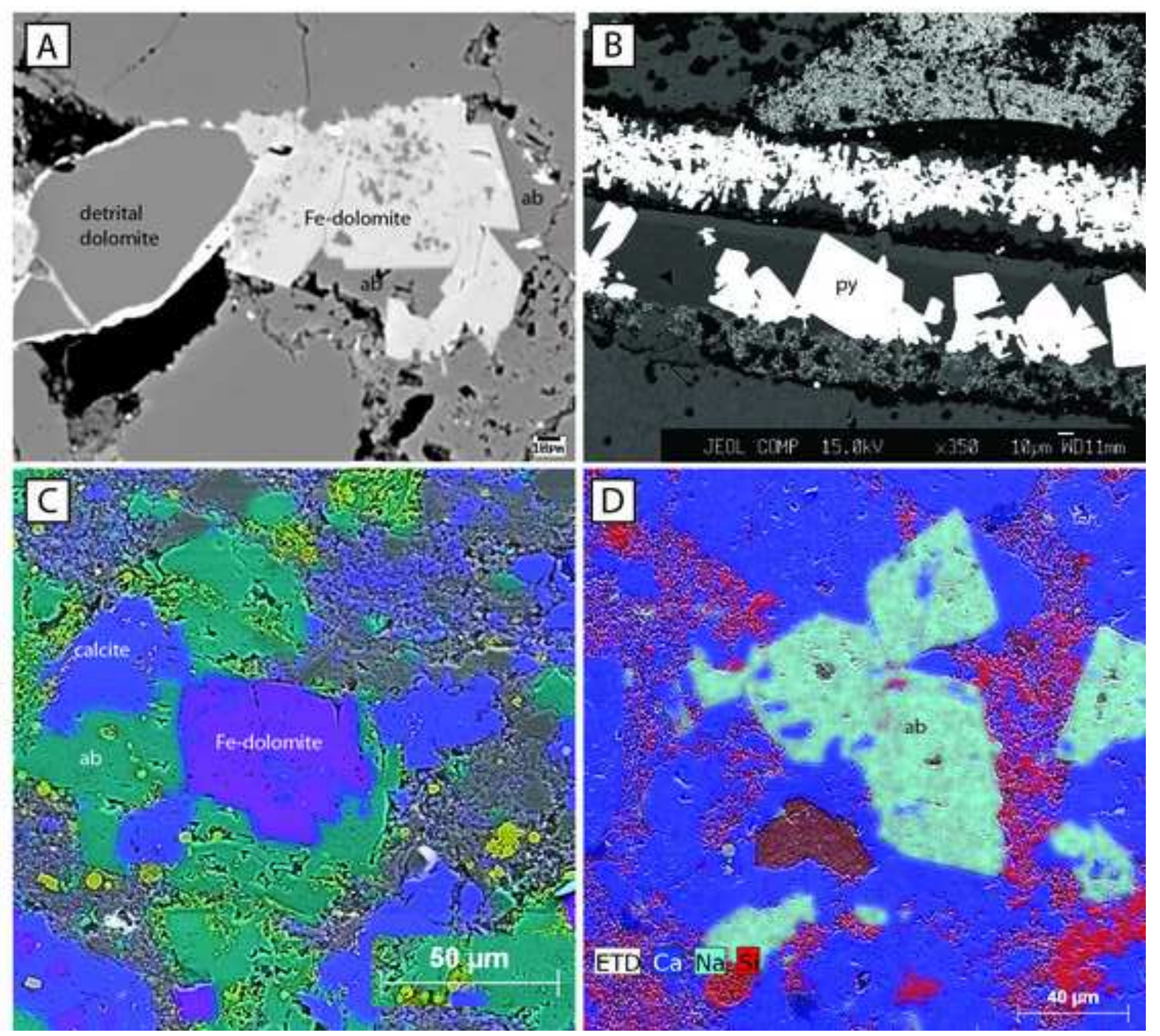




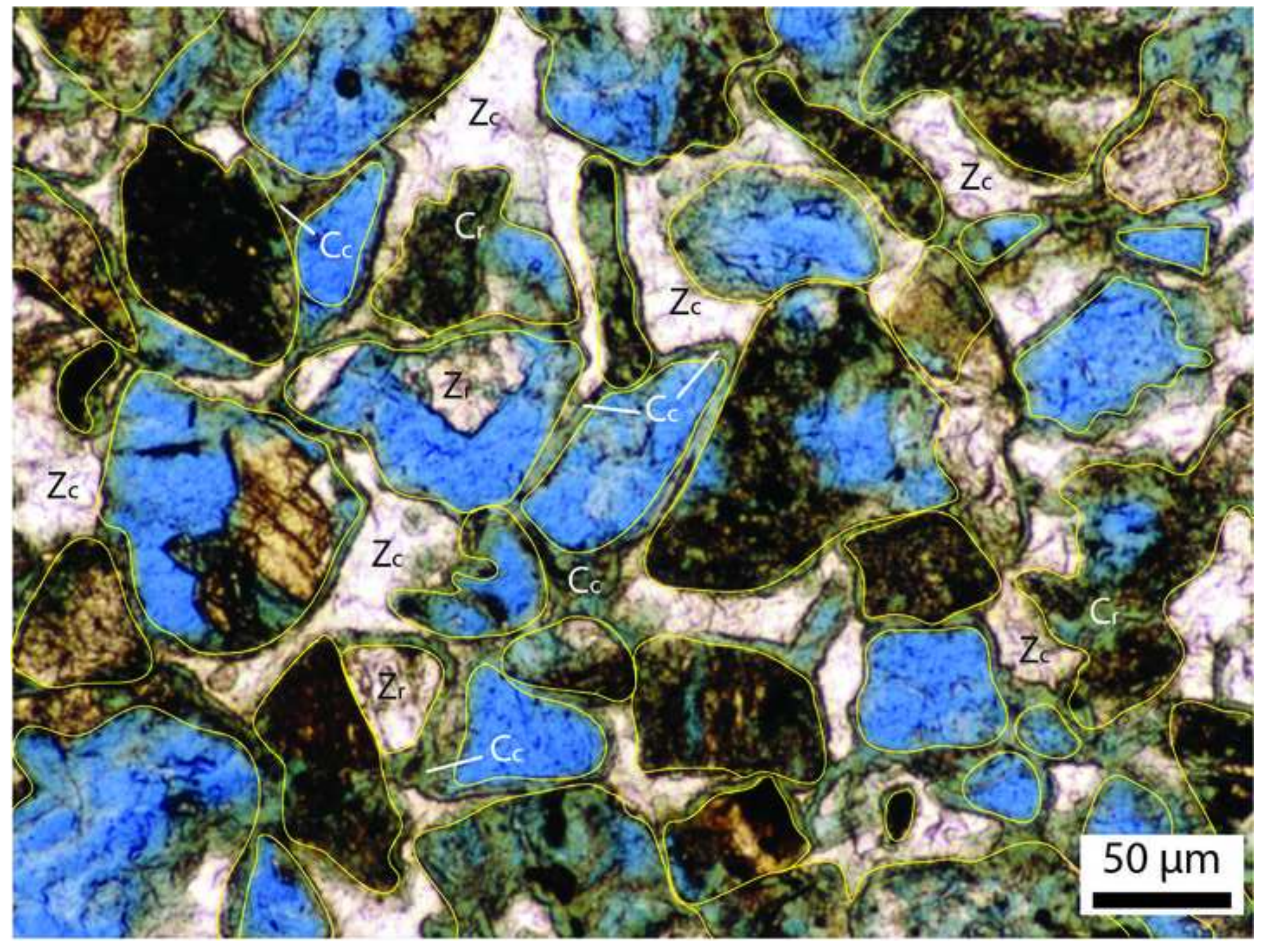




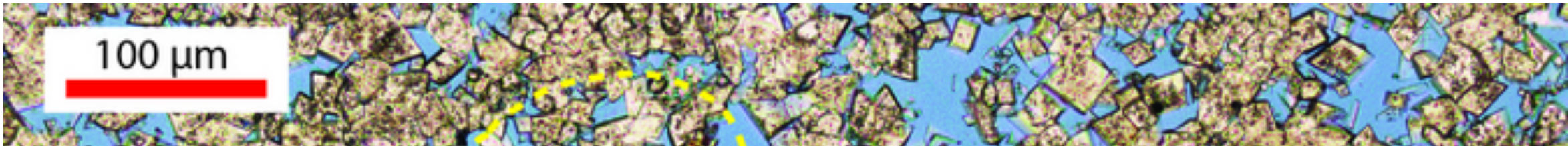

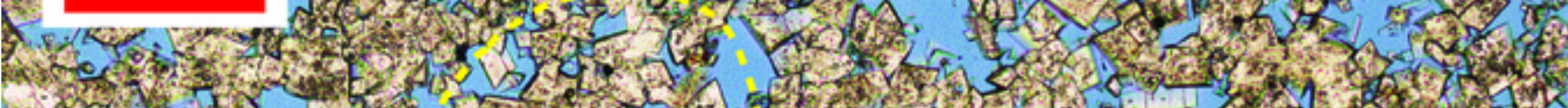

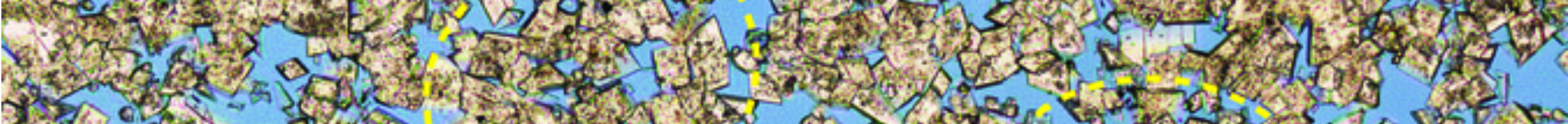

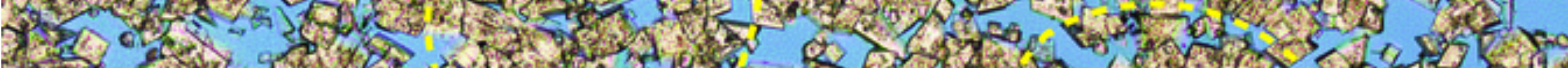

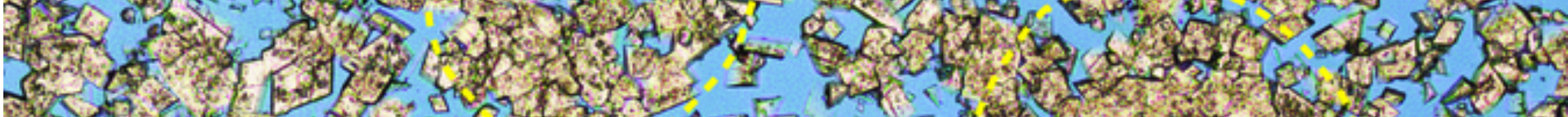

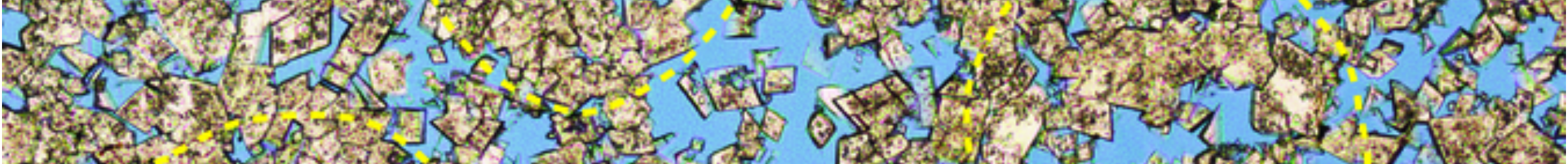
me a 10 .

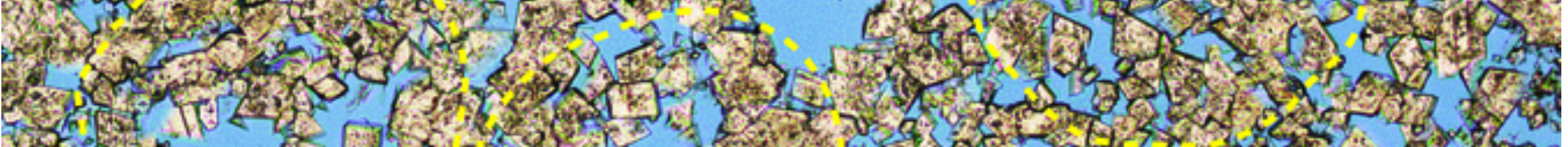

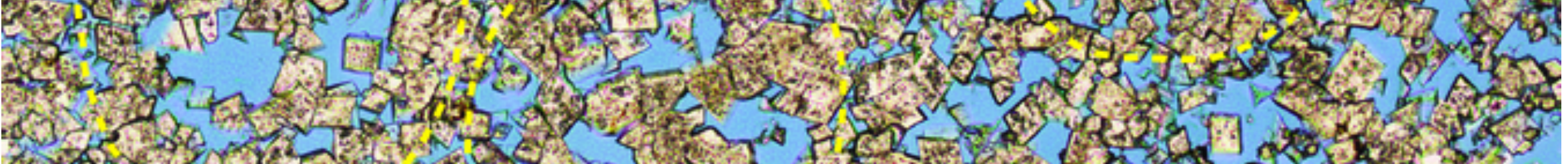

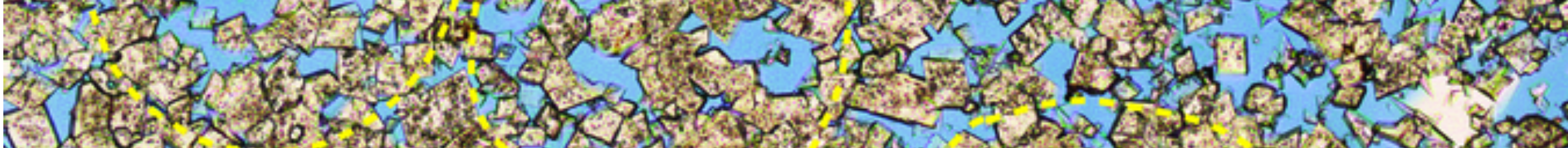

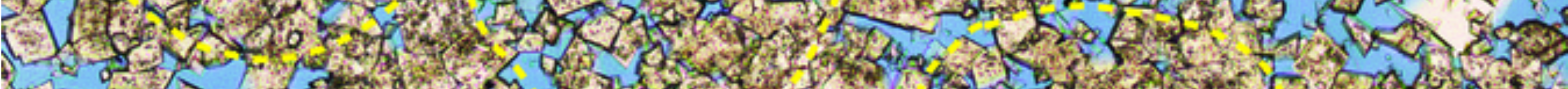

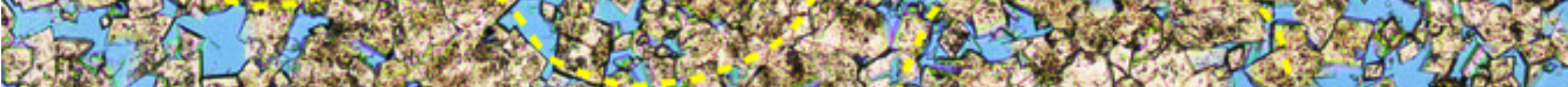

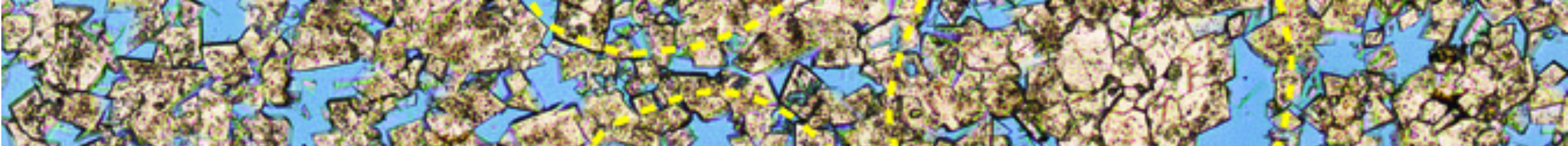

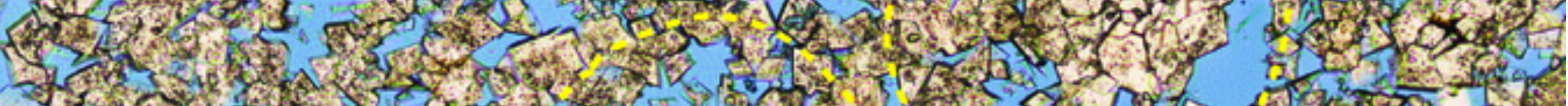

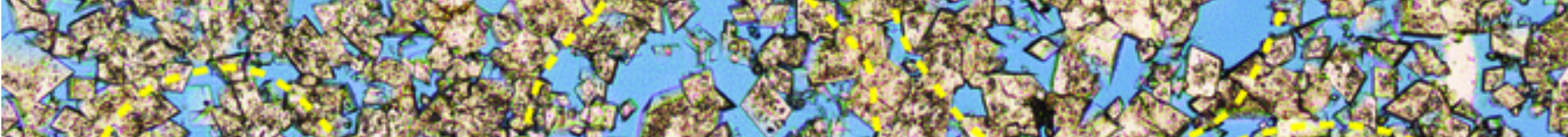

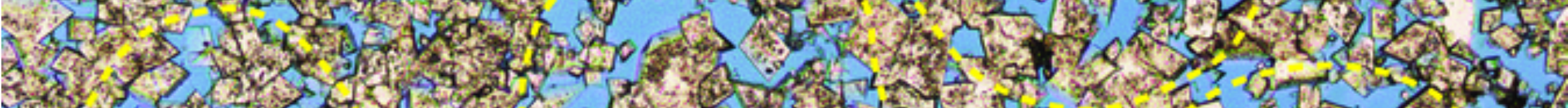

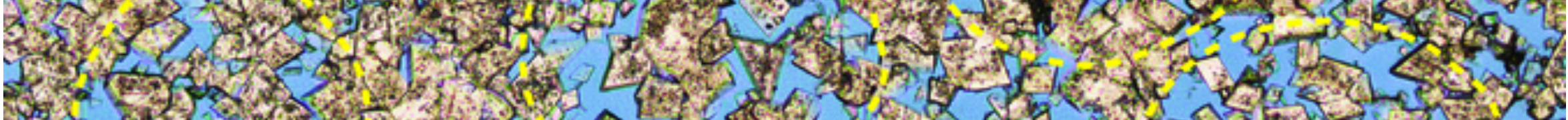

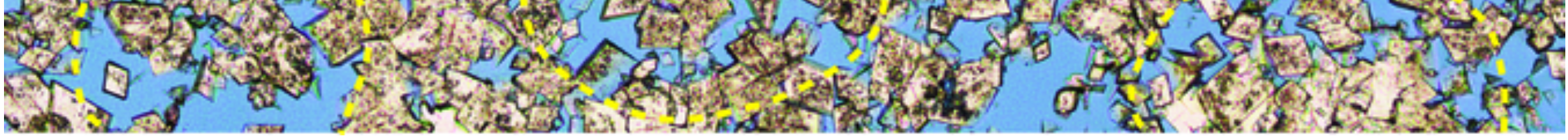


mechanical damage during grinding plucks material that reveals the underlying clear adhesive and glass.

rock slice is $30 \mu \mathrm{m}$ thick in a standard thin section

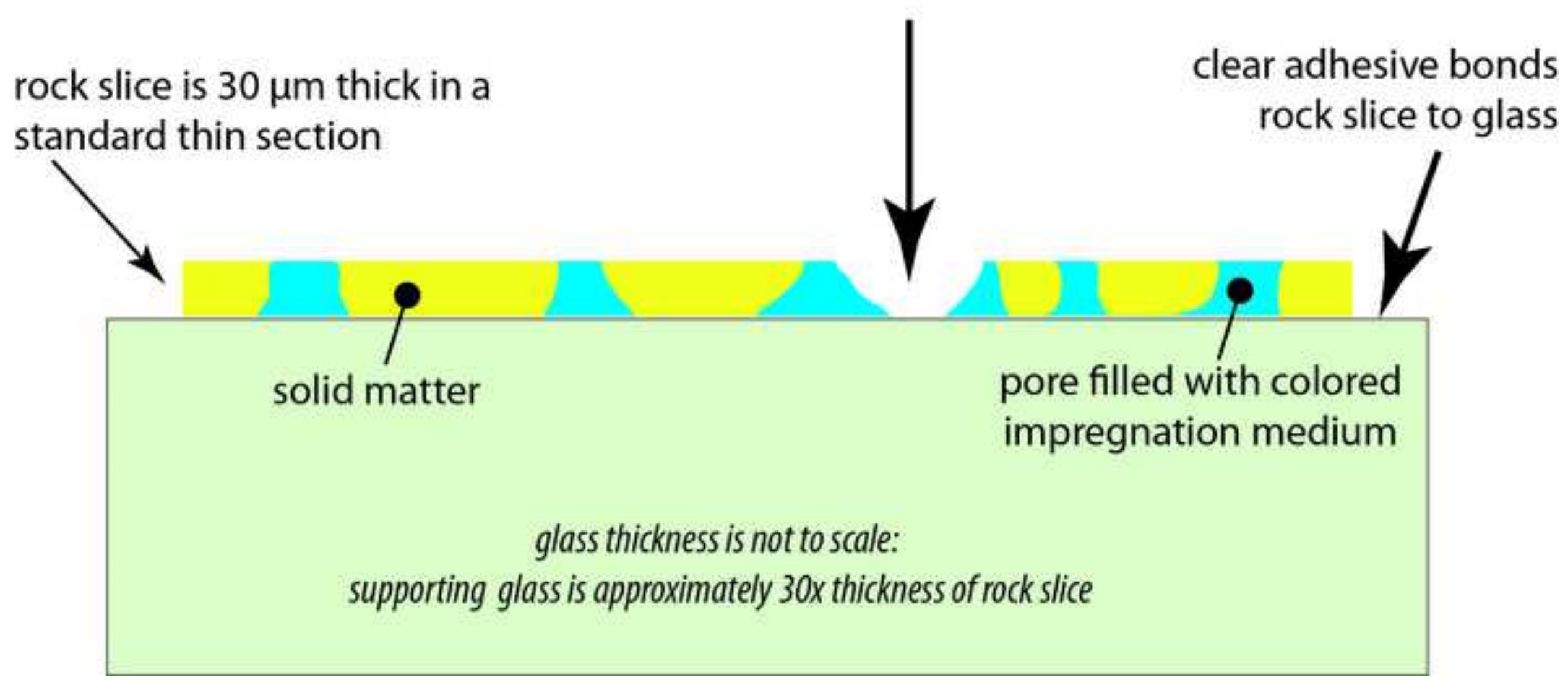



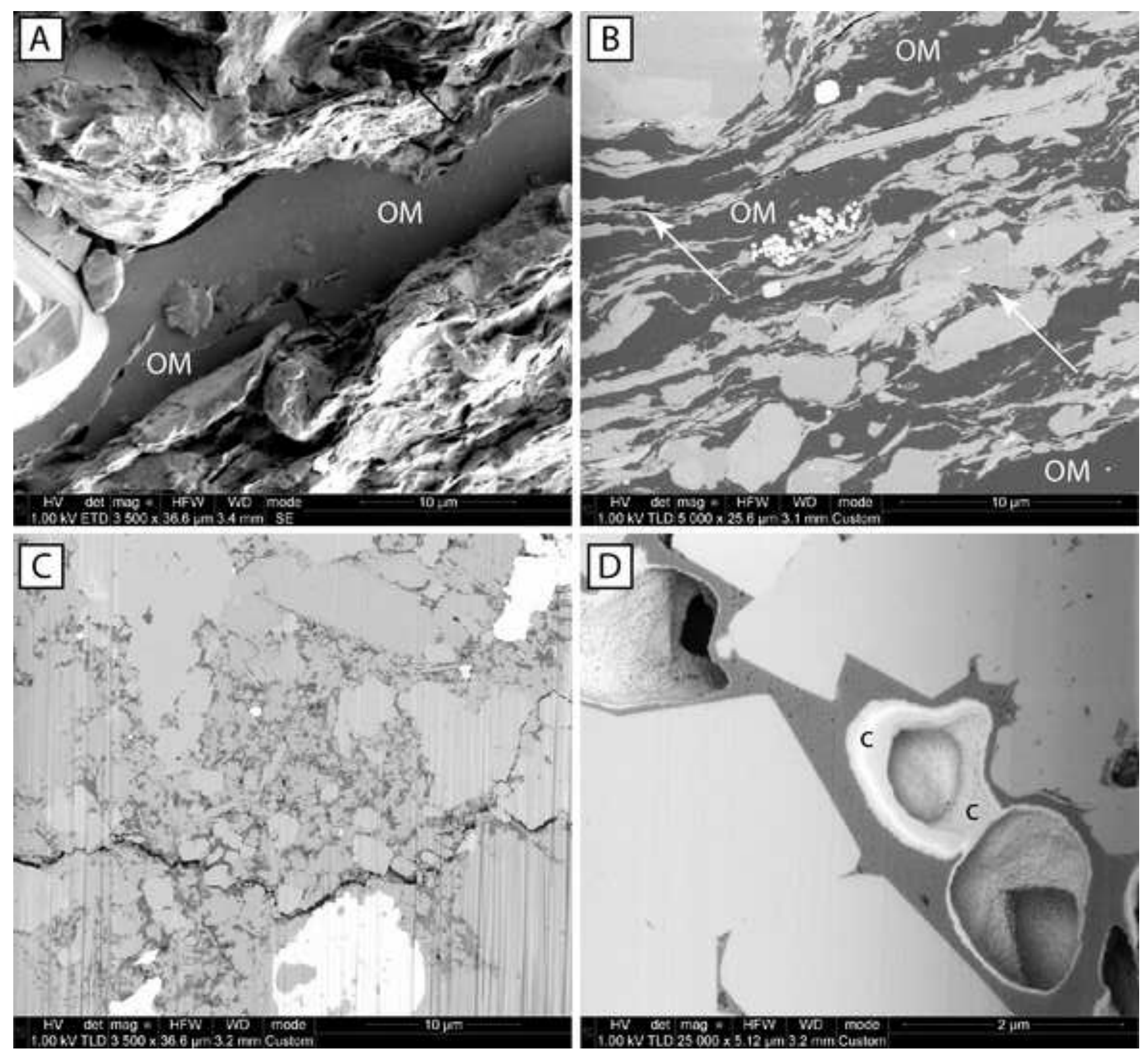

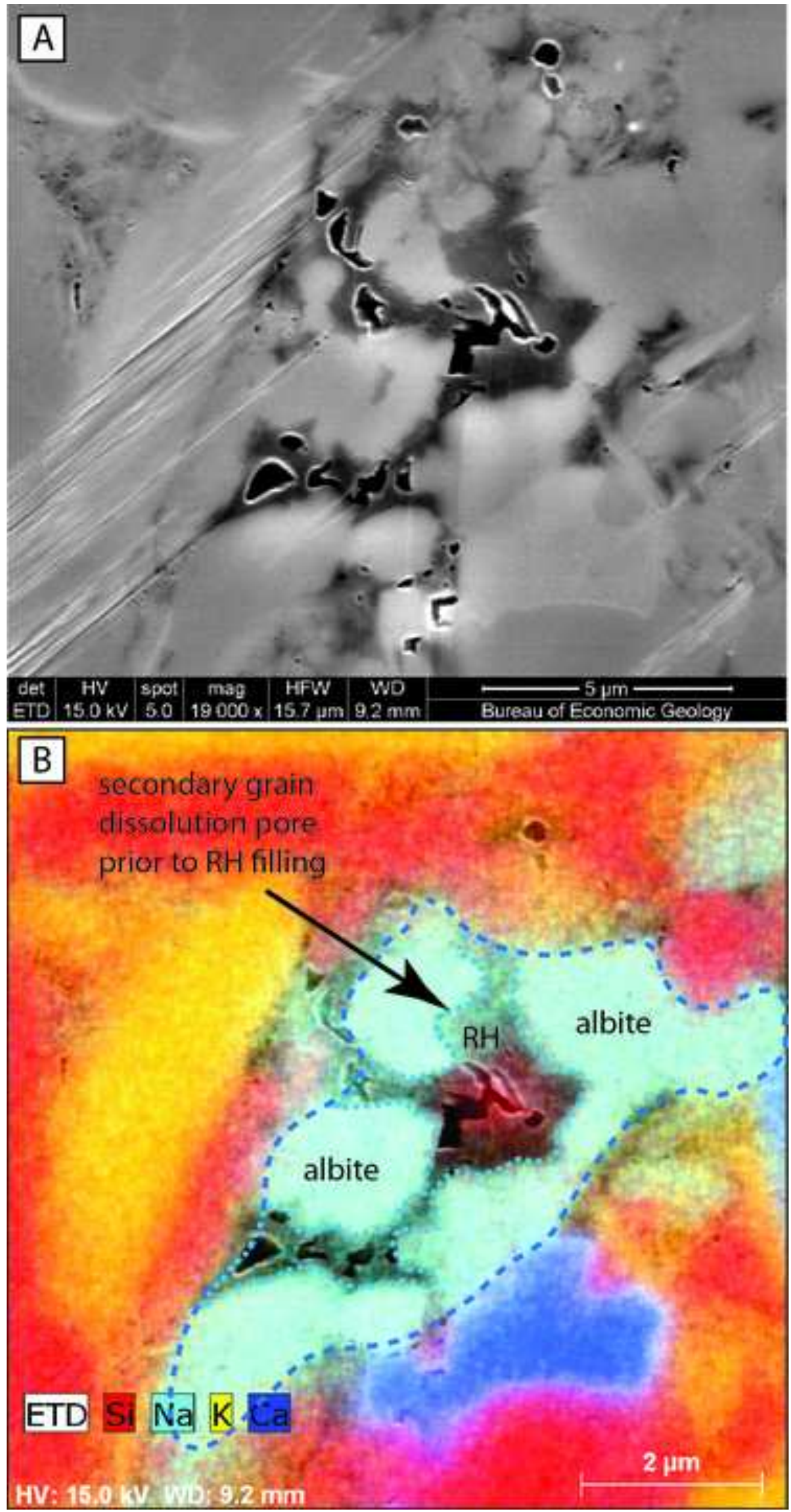


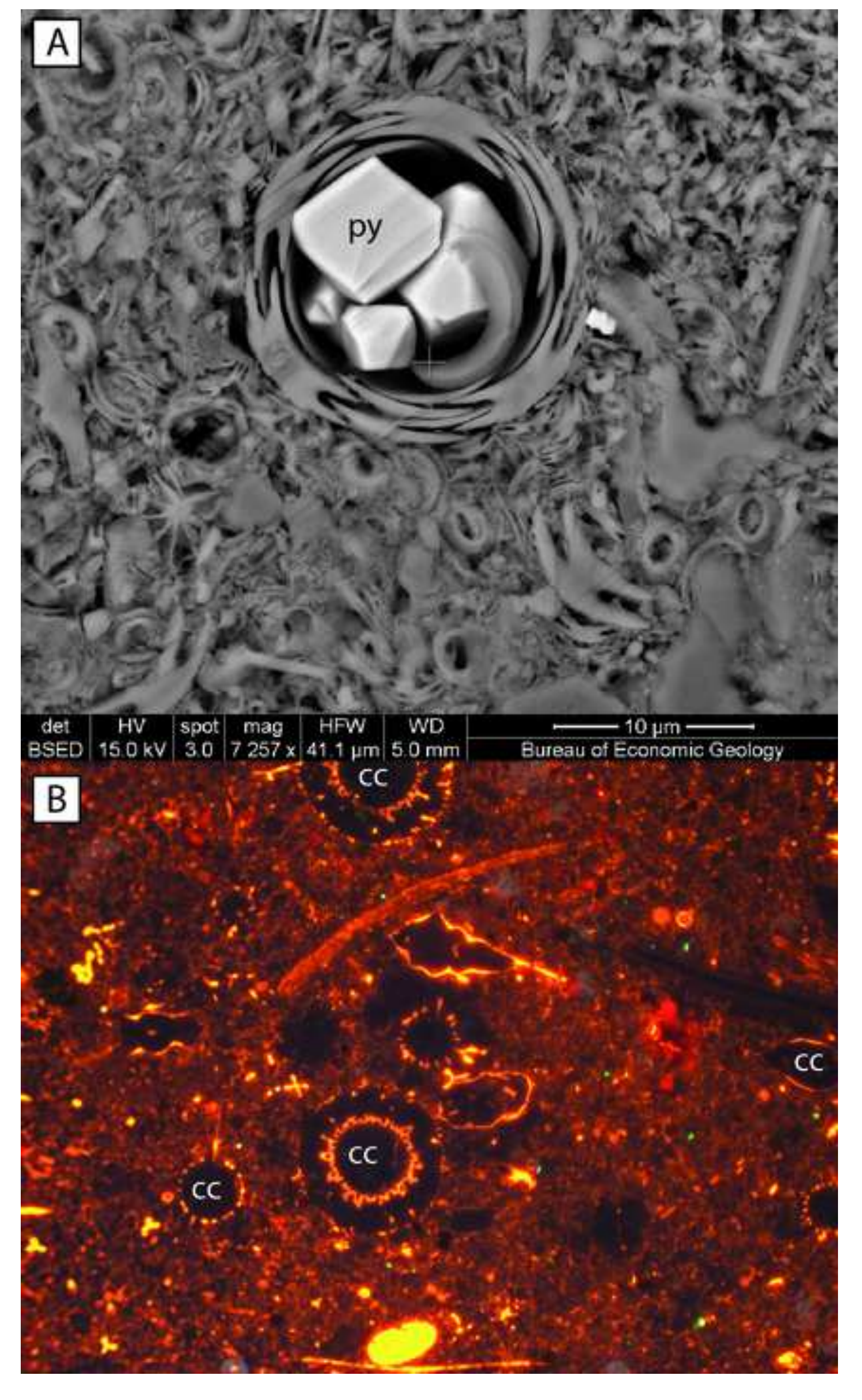

Figure 11 
Table 1. Methodologies for imaging sedimentary rocks.

\begin{tabular}{|c|c|c|c|c|c|c|c|c|}
\hline & Method & $\begin{array}{l}\text { Practical } \\
\text { Resolution }\end{array}$ & $\begin{array}{l}\text { Compositional } \\
\text { information }\end{array}$ & $\begin{array}{l}\text { Sample } \\
\text { preparation }\end{array}$ & $\begin{array}{l}\text { Conductive } \\
\text { Coating }\end{array}$ & $\begin{array}{c}\text { Special } \\
\text { considerations: } \\
\text { Sample prep } \\
\end{array}$ & $\begin{array}{c}\text { Special } \\
\text { considerations: } \\
\text { Other } \\
\end{array}$ & $\begin{array}{l}\text { Use in Sedimentary } \\
\text { Petrology }\end{array}$ \\
\hline \multicolumn{9}{|c|}{ Light Microscopy } \\
\hline \multicolumn{9}{|c|}{ Reflected light methods } \\
\hline 1 & Stereo reflected light & $10 \mu \mathrm{m}$ & by skilled interpretation & $\begin{array}{l}\text { broken surfaces, thin } \\
\text { sections, polished sections }\end{array}$ & none & & $\begin{array}{c}\text { generally }<100 x \\
\text { instrument magnification }\end{array}$ & $\begin{array}{l}\text { low-magnification view of surface texture; } \\
\text { component size, shape, and color }\end{array}$ \\
\hline 2 & Reflected, polarized light $^{1}$ & $1 \mu \mathrm{m}$ & yes & $\begin{array}{l}\text { polished sections or } \\
\text { surfaces }\end{array}$ & $\begin{array}{l}\text { usually none, C- } \\
\text { coating OK }\end{array}$ & & & $\begin{array}{l}\text { mineralogy, crystal size, shape, luster, } \\
\text { and color of components that do not } \\
\text { transmit light }\end{array}$ \\
\hline \multicolumn{9}{|c|}{$\underline{\text { Transmitted light methods }}$} \\
\hline 3 & Transmitted, plane-polarized light $(\mathrm{ppl})^{2}$ & $1 \mu \mathrm{m}$ & yes & $\begin{array}{l}\text { thin sections or polished } \\
\text { sections; } 30 \mu \mathrm{m} \text { thickness } \\
\text { standard; thinner if the rock } \\
\text { does not transmit light well }\end{array}$ & $\begin{array}{l}\text { usually none, C- } \\
\text { coating OK }\end{array}$ & & $\begin{array}{l}\text { imaging of pores requires } \\
\text { use of colored } \\
\text { impregnation media }\end{array}$ & $\begin{array}{l}\text { mineralogy; crystal and pore size and } \\
\text { shape in materials that transmit light }\end{array}$ \\
\hline 4 & Transmitted, cross-polarized light $(\mathrm{xpl})^{2}$ & $1 \mu \mathrm{m}$ & yes & $\begin{array}{l}\text { thin sections or polished } \\
\text { sections; } 30 \mu \mathrm{m} \text { thickness } \\
\text { standard; thinner if the rock } \\
\text { does not transmit light well }\end{array}$ & $\begin{array}{l}\text { usually none, C- } \\
\text { coating OK }\end{array}$ & & $\begin{array}{l}\text { slight un-crossing of } \\
\text { polarizers yields better } \\
\text { photography }\end{array}$ & $\begin{array}{l}\text { mineralogy; crystal size and shape in } \\
\text { materials that polarize light }\end{array}$ \\
\hline 5 & Confocal transmitted light $^{3}$ & $0.5 \mu \mathrm{m}$ & by skilled interpretation & $\begin{array}{l}\text { thick sections; up to } 500 \\
\mu \mathrm{m} \text { data depth }\end{array}$ & none & & $\begin{array}{l}\text { requires translucent } \\
\text { specimen }\end{array}$ & $\begin{array}{l}\text { component size and shape in } 3 \mathrm{D} \text {; used } \\
\text { mostly for pore imaging and } \\
\text { characterization of microbial precipitates }\end{array}$ \\
\hline 6 & Real-time 3D transmitted light microscopy ${ }^{4}$ & $200 \mathrm{~nm}$ & by skilled interpretation & $\begin{array}{l}\text { polished sections; up to } \\
100 \mu \mathrm{m} \text { thick }\end{array}$ & $\begin{array}{l}\text { usually none, C- } \\
\text { coating OK }\end{array}$ & & $\begin{array}{l}\text { requires translucent } \\
\text { specimens }\end{array}$ & component size and shape in $3 \mathrm{D}$ \\
\hline \multicolumn{9}{|c|}{ Stimulated emissions } \\
\hline 7 & UV-fluorescence ${ }^{5}$ & $1 \mu \mathrm{m}$ & by skilled interpretation & $\begin{array}{l}\text { polished sections or } \\
\text { surfaces }\end{array}$ & none & & $\begin{array}{l}\text { UV fluorescent dye can } \\
\text { be used to highlight } \\
\text { microporosity }\end{array}$ & $\begin{array}{l}\text { trace element zoning, organic matter } \\
\text { maturity; microbe detection; micropore } \\
\text { distribution }\end{array}$ \\
\hline 8 & Cold-cathode cathodoluminescence $^{6}$ & $1 \mu \mathrm{m}$ & by skilled interpretation & $\begin{array}{l}\text { polished sections or } \\
\text { surfaces }\end{array}$ & none & & & $\begin{array}{l}\text { trace element variations within mineral } \\
\text { species }\end{array}$ \\
\hline 9 & Coherent anti-Stokes Raman Scattering (CARS) ${ }^{7}$ & $1 \mu \mathrm{m}$ & $\begin{array}{l}\text { contrasts chemical } \\
\text { compounds through a } \\
\text { sensitivity to bonding }\end{array}$ & polished surface & no & & very new to geosciences & organic matter composition \\
\hline \multicolumn{9}{|c|}{ Scanning Electron Microscopy ${ }^{*}$} \\
\hline 10 & Secondary electron (SE) imaging ${ }^{8}$ & $1 \mathrm{~nm}$ & no & $\begin{array}{l}\text { broken, polished, or ion } \\
\text { milled surfaces }\end{array}$ & $\begin{array}{l}\text { numerous possible } \\
\text { coatings }\end{array}$ & $\begin{array}{l}\text { samples need to generally } \\
\text { clean and dry, coating } \\
\text { may be omitted in low } \\
\text { vaccuum imaging at cost } \\
\text { of resolution }\end{array}$ & $\begin{array}{l}\text { SE contrast can be } \\
\text { difficult to interpret. SE } \\
\text { more susceptible to } \\
\text { charging. }\end{array}$ & component shapes, sizes \\
\hline 11 & 3D SE imaging ${ }^{9}$ & $1 \mathrm{~nm}$ & no & $\begin{array}{l}\text { progressive slices imaged } \\
\text { after milling by focused ion } \\
\text { beam (FIB) }\end{array}$ & $\begin{array}{l}\text { any coating will be } \\
\text { removed by FIB }\end{array}$ & $\begin{array}{l}\text { carbonate samples } \\
\text { present redeposition issue } \\
\text { for FlB }\end{array}$ & $\begin{array}{l}\text { image volume limited to a } \\
\text { few microns across }\end{array}$ & component shapes, sizes in 3D \\
\hline 12 & Back-scattered electron (BSE) imaging ${ }^{10}$ & $5 \mathrm{~nm}$ & $\begin{array}{l}\text { by skilled interpretation } \\
\text { in combination with } \\
\text { EDS elemental } \\
\text { identification }\end{array}$ & $\begin{array}{l}\text { polished or ion milled } \\
\text { surfaces }\end{array}$ & $\begin{array}{l}\text { carbon or thin } \\
\text { metallic }\end{array}$ & $\begin{array}{l}\text { carbonate samples } \\
\text { present redeposition issue } \\
\text { for ion milling }\end{array}$ & $\begin{array}{c}\text { distinction between } \\
\text { materials not as good } \\
\text { with high atomic number } \\
\text { materials }\end{array}$ & $\begin{array}{l}\text { compositional information; component } \\
\text { shapes, sizes }\end{array}$ \\
\hline 13 & Energy-dispersive spectroscopy (EDS) X-ray mapping ${ }^{11}$ & $0.5 \mu \mathrm{m}$ & $\begin{array}{l}\text { yes, for major, some } \\
\text { minor elements, Boron } \\
\text { and heavier elements }\end{array}$ & $\begin{array}{l}\text { polished or ion milled } \\
\text { surfaces }\end{array}$ & $\begin{array}{l}\text { carbon or thin } \\
\text { metallic }\end{array}$ & $\begin{array}{l}\text { quantitative EDS requires } \\
\text { very flat, homogeneous } \\
\text { surfaces, conductive } \\
\text { coating must be of known } \\
\text { thickness }\end{array}$ & $\begin{array}{l}\text { beam energies sufficient } \\
\text { to cause damage to } \\
\text { some materials }\end{array}$ & mineral shapes, sizes \\
\hline
\end{tabular}


mineral shapes, sizes; compositiona

beam energies sufficient

to cause damage to

area limited to $>150 \mathrm{X}$ compositional information; component

machine magnification;

lower magnification

shapes, sizes

mages require mosaic

$$
\text { mapping }
$$

equires low-vaccum component shapes, sizes; compositional operation variation within mineral species, defects

17 electron back-scatter diffraction (EBSD); orientation contrast imaging polished or ion mille
surfaces

samples need to be

clays problematic mineralogy; crystal size, shape, an

\section{Transmission Electron Microscopy}

\begin{tabular}{|c|c|c|c|c|c|c|c|c|}
\hline 18 & TEM imaging ${ }^{14}$ & $.1-.2 \mathrm{~nm}$ & $\begin{array}{l}\text { Bright field for mass- } \\
\text { thickness contrast, } \\
\text { dark field for } \\
\text { crystallographic } \\
\text { contrast; minerals can } \\
\text { be identified by skilled } \\
\text { interpretation }\end{array}$ & $\begin{array}{l}\text { thinned specimens }(<100 \\
\mathrm{nm})\end{array}$ & none & $\begin{array}{l}\text { want to reduce } \\
\text { amorphous layer from } \\
\text { milling, samples can be } \\
\text { fragile }\end{array}$ & $\begin{array}{l}\text { stringent room } \\
\text { requirements }\end{array}$ & component size, shape \\
\hline 19 & Selected area electron diffraction (SAED) ${ }^{15}$ & $.1-.2 \mathrm{~nm}$ & yes & $\begin{array}{l}\text { thinned specimens }(<100 \\
\mathrm{nm})\end{array}$ & none & $\begin{array}{l}\text { sample should be thin } \\
\text { enough that } 2 \text { grains are } \\
\text { not overlying each other }\end{array}$ & $\begin{array}{l}\text { all materials within the } \\
\text { diffraction aperture will } \\
\text { contribute to pattern }\end{array}$ & mineralogy, crystal structure \\
\hline 20 & Electron Energy Loss Spectroscopy (EELS) & $.1-.2 \mathrm{~nm}$ & yes & $\begin{array}{l}\text { thinned specimens }(<100 \\
\mathrm{nm})\end{array}$ & none & & $\begin{array}{l}\text { Typically must consult } \\
\text { library of spectra for } \\
\text { identification, beam } \\
\text { damage an issue }\end{array}$ & elemental composition, phase \\
\hline \multicolumn{9}{|c|}{ Scanning Transmission Electron Microscopy } \\
\hline 21 & bright-field (BF) ${ }^{17}$ & $.1-.2 \mathrm{~nm}$ & $\begin{array}{c}\text { mass-thickness } \\
\text { contrast; minerals can } \\
\text { be identified by skilled } \\
\text { interpretation }\end{array}$ & $\begin{array}{l}\text { thinned specimens }(<100 \\
\mathrm{nm})\end{array}$ & none & same as TEM & $\begin{array}{l}\text { can be performed in a } \\
\text { properly equiped SEM or } \\
\text { a TEM }\end{array}$ & $\begin{array}{c}\text { component size, shape, higher resolution } \\
\text { EDS }\end{array}$ \\
\hline & annular dark field(ADF) ${ }^{18}$ & $.1-.2 \mathrm{~nm}$ & $\begin{array}{l}\text { crystallographic } \\
\text { contrast; minerals can } \\
\text { be identified by skilled } \\
\text { interpretation }\end{array}$ & $\begin{array}{l}\text { thinned specimens }(<100 \\
\mathrm{nm})\end{array}$ & none & same as TEM & $\begin{array}{l}\text { can be performed in a } \\
\text { properly equiped SEM or } \\
\text { a TEM }\end{array}$ & component size, shape, crystallinity \\
\hline 22 & high-angle annular dark field (HAADF) $)^{19}$ & $.1-.2 \mathrm{~nm}$ & $\begin{array}{c}\text { atomic number } \\
\text { contrast; minerals can } \\
\text { be identified by skilled } \\
\text { interpretation }\end{array}$ & $\begin{array}{l}\text { thinned specimens }(<100 \\
\mathrm{nm})\end{array}$ & none & same as TEM & $\begin{array}{c}\text { can be performed in a } \\
\text { properly equiped SEM or } \\
\text { a TEM }\end{array}$ & component size, shape \\
\hline 23 & Helium Ion Microscopy ${ }^{20}$ & $<1 \mathrm{~nm}$ & $\begin{array}{l}\text { atomic number } \\
\text { contrast from } \\
\text { backscattered ions }\end{array}$ & $\begin{array}{l}\text { broken, polished, or ion } \\
\text { milled sections }\end{array}$ & no & & $\begin{array}{l}\text { charge control by flood } \\
\text { gun may be needed }\end{array}$ & component size, shape \\
\hline \multicolumn{9}{|c|}{ Secondary lon Mass Spectroscopy } \\
\hline 24 & SIMS imaging ${ }^{21}$ & 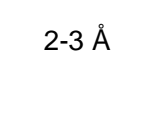 & $\begin{array}{l}\text { major, minor, trace, } \\
\text { and isotopic } \\
\text { compositions }\end{array}$ & polished surfaces & no & & $\begin{array}{l}\text { Ion implantation/damage } \\
\text { can be an issue; charge } \\
\text { control by flood gun }\end{array}$ & $\begin{array}{l}\text { trace element and isotopic variations } \\
\text { within mineral species }\end{array}$ \\
\hline
\end{tabular}


Atomic Force Microscopy

\begin{tabular}{|c|c|c|c|c|c|c|c|c|}
\hline 26 & AFM imaging $^{23}$ & $\begin{array}{c}\text { Vertical: } 1-2 \AA \text {; } \\
\text { Horizontal: } 1-2 \mathrm{~nm} \text {; Field } \\
\text { of view limited to } \sim 100 \\
\mu \mathrm{m} .\end{array}$ & $\begin{array}{l}\text { Limited compositional } \\
\text { information by } \\
\text { interpretation }\end{array}$ & $\begin{array}{l}\text { Sample must be relatively } \\
\text { flat }\end{array}$ & no & & $\begin{array}{l}\text { Large topographical } \\
\text { features can damage tip. } \\
\text { Tip convolutions result in } \\
\text { inacurate representation } \\
\text { of topography. }\end{array}$ & component size and shape \\
\hline 27 & Peak-force QNM ${ }^{\top \mathrm{T} 24}$ & $<5 \mathrm{~nm}$ & $\begin{array}{l}\text { Limited compositional } \\
\text { information by } \\
\text { interpretation }\end{array}$ & $\begin{array}{l}\text { Sample must be relatively } \\
\text { flat }\end{array}$ & no & & $\begin{array}{l}\text { Large topographical } \\
\text { features should be } \\
\text { avoided due to tip } \\
\text { damage }\end{array}$ & $\begin{array}{l}\text { mapping of elastic moduli in specific } \\
\text { components; possible use in } \\
\text { discriminating OM types }\end{array}$ \\
\hline 28 & X-ray Computed Tomography $(\mathrm{XCT})^{25}$ & $\begin{array}{l}1 \mu \mathrm{m} \text { for microXCT; } 50 \\
\mathrm{~nm} \text { for nanoXCT; Higher } \\
\text { magnifications require } \\
\text { thinner samples or longer } \\
\text { exposure times }\end{array}$ & $\begin{array}{l}\text { composition } \\
\text { differences based on } \\
\text { density and atomic } \\
\text { number }\end{array}$ & $\begin{array}{l}\text { Samples usually shaped } \\
\text { into cubes or cylinders of } \\
\text { mm dimensions }\end{array}$ & no & $\begin{array}{l}\text { nanoXCT requires small } \\
\text { sizes }\end{array}$ & $\begin{array}{l}\text { Contrast agents can be } \\
\text { added to highlight } \\
\text { accessible porosity. For } \\
\text { nanoCT, laser ablation or } \\
\text { FIB milling used to create } \\
\text { optimal sample size. }\end{array}$ & $\begin{array}{l}\text { component size, shape in 3D; including } \\
\text { fluid distributions }\end{array}$ \\
\hline 29 & Scanning Acoustic Microscopy ${ }^{26}$ & $1 \mu \mathrm{m}$ & $\begin{array}{l}\text { Limited compositional } \\
\text { information by skilled } \\
\text { interpretation }\end{array}$ & polished surface & no & & & $\begin{array}{l}\text { Topography and acoustic impedance } \\
\text { (elastic properties) of constituent } \\
\text { materials }\end{array}$ \\
\hline 30 & Small-angle X-ray Scattering (SAXS) ${ }^{27}$ & $1 \mathrm{~nm}$ & none & $\begin{array}{c}\text { sample dimension } \\
\text { considerations of } \\
\text { apparatus }(\mathrm{mm} \text { to } \mathrm{cm})\end{array}$ & no & & & component size and shape \\
\hline 31 & Small-angle Neutron Scattering (SANS) ${ }^{28}$ & $1 \mathrm{~nm}$ & $\begin{array}{l}\text { determination of pore } \\
\text { host material }\end{array}$ & $\begin{array}{c}\text { sample dimension } \\
\text { considerations of } \\
\text { apparatus }(\mathrm{mm} \text { to } \mathrm{cm})\end{array}$ & no & $\begin{array}{l}\text { deutrated fluids better for } \\
\text { saturation experiments } \\
\text { due to higher scattering } \\
\text { length density }\end{array}$ & $\begin{array}{c}\text { More sensitive to light } \\
\text { elements than SAX; } \\
\text { limited to features }<100 \\
\mathrm{~nm}\end{array}$ & component size and shape \\
\hline 32 & Synchrotron X-ray Fluorescence Imaging (SXRF) ${ }^{29}$ & $1 \mu \mathrm{m}$ & $\begin{array}{l}\text { major, minor, and trace } \\
\text { elements }\end{array}$ & $\begin{array}{l}\text { roughly flat or polished } \\
\text { surfaces }\end{array}$ & no & & & small-scale elemental mapping \\
\hline
\end{tabular}

\# SEM imaging performed without a coating requires an instrument capable of operation at low vacuum.

${ }^{*}$ SEM resolutions are reported for techniques performed on a field-emission instrument

References

1 Craig and Vaughn, 1994

2 Nesse, 2013

3 Petford et al., 1999

4 Seyedolali et al., 1994

5 Mille et al., 1988; Bhartia et al., 2008; Yanguas and Dravis, 1985

6 Boggs, 2006; Coulson, 2014

7 Burrus et al., 2012

8 O'Brien and Slatt, 1990

9 Heath et al., 2011; Curtis et al., 2012 
10 White et al., 1984

11 Reed et al.., 1996

12 Watt et al., 2000

13 Ohfuji et al., 2005; Haddad et al., 2006

14 Lee 2010

15 Nieto et al., 1996; Kim et al., 1999

16 Kanitpanyacharoen et al., 2012; Walters et al., 2014

17 Curtis et al., 2010

18 Curtis et al., 2010

19 Bernard et al., 2012

20 King et al., 2015

21 Elphick et al., 1991

22 Kuhlman et al., 2001

23 Javadpour et al., 2012

24 Eliyahu et al., 2015

25 Cnudde et al., 2014; Ketcham et al., 2001; Van Geet et al., 2000

26 Prasad, 1997

27 Radlinski, 2004

28 Radlinski, 2006; Ruppert, 2013; Clarkson et al., 2012

29 Pushie et al., 2014 